\title{
Does Asymmetric Signification Rely on Conventional Rules? Two Answers from Ancient Indian and Greek Sources*
}

\author{
VALERIA MELIS \\ University of Cagliari, Italy (valeriamelis2000@gmail.com) \\ Tiziana Pontillo \\ University of Cagliari, Italy (pontillo@unica.it)
}

\begin{abstract}
The topic of asymmetry between the semantic and the phono-morphological levels of language emerges very early in Indian technical and speculative reflections as it also does in pre-socratic Greek thought. A well established relation between words and the objects they denote (the so-called one-to-one principle of correspondence) seems to have been presupposed for each analysis of the signification long before its earliest statement.

The present paper aims at shedding light on two different patterns of tackling the mentioned problem. The first approach sees asymmetry as an exception to the regular correspondence between language and reality, whereas the second approach considers language in itself as a conceptualisation which does not faithfully represent reality. In the latter case, asymmetry is no longer an exception, but the rule.
\end{abstract}

Keywords: ancient Greek speculation on language; ancient Indian linguistics; language as a means of knowledge; linguistic asymmetry; paretymologies; polysemy; synonymy; substitution

\section{Introduction: the Alleged Symmetry between Words and Objects}

The present joint paper focuses on the topic of asymmetry between the semantic and the phonomorphological levels of language which emerges very early on in Indian technical and speculative reflections, as it also does in pre-socratic Greek thought. Our shared research aims at shedding light on two different patterns of explaining such a linguistic phenomenon. The first approach sees asymmetry as an exception to the regular correspondence between language and reality, whereas the second approach considers language itself as a conceptualization that does not faithfully represent reality, and hence, asymmetry is no longer an exception, but the rule.

Before dealing with asymmetry, we need to take a short step back and depict a remote and common background where the symmetry between words and the objects they denote constitutes a given datum. In fact, these two opposed historical interpretations, in which linguistic asymmetry was either a natural or a conventional exception, at a certain point in time, actually derived from the reflections on this alleged symmetry between words and objects.

The first problematic way of considering asymmetry as an exception depends, in our opinion, on a presupposed basic symmetry of language, namely, on a sort of one-to-one principle of correspondence between words and the objects they denote 1 - which we assume was presupposed both in ancient India and in ancient Greece. This principle is clearly expressed in the Panninian grammatical tradition only from the $3^{\text {rd }}$ century BCE onwards. ${ }^{2}$ According to Kātyāyana, words as a rule apply per object: one and only one word-form matches with one and only one object. ${ }^{3}$ 
Mahäbbäsya $[\mathrm{M}] 1.2331 .16$ Värttika $[\mathrm{Vt}]^{4} 1$ ad Aștādhyāyz̃ $[\mathrm{A}]^{5}$ 1.2.64:6 pratyartham śabdanivesán naikenānekasyābhidhānam,

"Because words apply per object, 7 there is no denotation of many objects by one word."

\section{1.233 1.20 Vt 2 ad A 1.2.64: tatrānekārthäbhidhāne 'nekaśabdatvam,}

"Where more than one object is denoted, more than one word [has to be used]."

More generally, each word is supposed (probably by Kātyāyana once again) ${ }^{8}$ to be permanently endowed with a precise meaning, so that each grammar rule merely aims to justify this usage or to establish some specific restriction in some way: ${ }^{9}$

M 1.6.16: siddhe śabdārthasambandhe lokato 'rthaprayukte śabdaprayoge śästrena dharmaniyamah, ${ }^{10}$ "When [it is assumed that] there is a well-established relation between sabda and artha (between word-forms and their objects), ${ }^{11}$ which relies on everyday linguistic usage; [and] when [it is assumed that] the use of words is prompted by the object meant, ${ }^{12}$ the science [of grammar] [provides] a restriction [on the use of words] for the sake of merit."

As a consequence, the general background of the speculative context we are considering is constituted by a close relationship between reality and language, or better, between the objects of knowledge and the linguistic forms which are able to denote them. The use of words is prompted by the thing-meant, and, in the end, it depends on the intention of making something known, ultimately of conveying some meaning (through a verbal expression).

Moreover, a final and essential premiss might have been the way that verbal communication was supposed to work, which is clearly explained even later on in the following description by Patañjali (second century BCE):

M 1.18 11. 19-20 ad Śivasūtra 1 Vt 12: śrotropalabdhir buddhinirgrāhyah prayogenābhijvalita ākāśadeśab śabdah,

"Becoming perceptible through the ear, to be grasped by the intellect, enlightened by usage and residing in the ether: this is the word (sabda)." ${ }^{13}$

To sum up, word-forms (sabda) definitely play the role of causes in the Panninian framework and give rise to the cognition of objects (artha) in the mind of the participants in the communicative event. The addresser actually needs to employ words, for instance, to utter them, in order to arouse the relevant mental image in the mind of the addressee. Thus, the physical perception of words can really give rise to the relevant concepts.

Of course, we are keen to discover more about the previous speculative scenario in both India and Greece, which has brought us to preliminarily concentrate on some evidence that, in our opinion, proves that both Indians and Greeks were also convinced of this correspondence before the third century BCE.

The ancient popular etymologies included in Vedic sources-or better, the etymologizing stylistic figures entailing an undeniable magico-linguistic intention on the part of the poets, as they are presented by Deeg ${ }^{14}$ — seem to rely on this belief. Already in the Rgveda $[\mathrm{RV}]^{15}$ and in the Atharvaveda, whose earliest hymns may date back to the twelfth century BCE, the paretymological connection between theonyms and the specific role played by the matching Gods is rooted in this principle of denotative integrality.

For instance, the ancient Vedic Saṃhitās regularly explain the etymological connection between the noun which denotes fire-Agni-and the nominal base which means "the first, that which is in front." 
Atharvaveda (Śaunakīya Recension) [AVŚ] ${ }^{16}$ 4.14.1:

ajó by àgnér ájanisțta sokāt só apaśyaj janitấram ágre $\left.\right|^{17}$

téna devá devátām ágrā āyan téna róhān rurubur médhyāsah |

"Since the goat was born from the heat of Agni, it saw [its] generator at the beginning; by means of this the gods as the first ones attained divine status; by means of this the [victims], fit for the sacrifice, ascended the ascending ones (the heights)." 18

Nirukta [Nir], ${ }^{19}$ a treatise on semantic analysis which belongs to the earliest technical literature in Sanskrit and likely dates back to the sixth-fifth century BCE, proposes the same linguistic connections between the name Agni and the nominal stem agra-, but in a less poetic and quite specialized manner: ${ }^{20}$

Nir 7.14: [...] agnih kasmät. agranì bhavati. agram yajñesu pranīyate.

"From what does [the noun] agni derive? It is the foremost. It is brought in the sacrifices at the beginning $[\ldots] . "$

Analogously, $p r t h i v \bar{~}$ (the earth/the Goddess Pṛthivī) is technically explained as "the wide [earth]" merely because of the link with the verb prath- "to spread" in Nir 1.14: prathanāt prthivity äbub, "They call it prtbivi on the basis of the verb 'to spread.' Of course, a more interpretative translation could be: "They call it prtbivi because it has been spread out," 21 since this name is the object of comparable etymological figures of speech in both the RV and in the AVŚ, where a specific agent, such as Indra, is often even singled out for the action (denoted by the verb prath'to spread out') which is linked to the analysed noun/name (prthivi). ${ }^{22}$ Nevertheless, Nirukta explicitly refuses excessive speculation on the motivation of the single relations between words. Instead, preference is given to a regular frame of correspondences among words, within which the single meanings can generally be smoothly detected.

Nir. 1.14: ka enām aprathayișat kim ädhāraś ceti. atha vai darśanena prthuh. aprathitā ced apy anyaỉ̆. athäpy evam sarva eva drsțapravādà upälabhyante

"'But who spread it, and what was the base?' (We reply that) it is indeed broad to look at, even if it is not spread by others. Otherwise, in this way, all known words can actually be found fault with.”

It is therefore a perceptible fact that the earth is wide and this in itself must suffice. Little does it matter if we do not know the diachronic story of this linguistic usage or the aetiological myth. A markedly technical and scientific stance in highlighting this kind of linguistic connection is thus intentionally inaugurated. Somehow, mere perception (pratyaksa), ${ }^{23}$ warrants the enunciated relation between the object of language and its denotation-in this case between the quality of being wide and the substance earth that possesses it, in other words between the qualifying word and the qualified object. The Earth is wide by nature, and by nature it has to be called "the wide one" per antonomasia. It cannot just be a convention.

Thus, a scientific method slowly originates from a poetic and stylistic pre-scientific way of focusing on the principles of signification. Visible items are linked with audible items, because two audible items that denote two comparable objects are, in turn, also comparable. Thus, language seems to be a reliable means of knowledge and its reliability can be proven on the basis of perception. We shall see that this principle of correspondence is not explicitly expressed in archaic Greek sources, but rather, it seems to be presupposed, precisely because it is questioned by the authors. On the other hand, there is actually less distance between the aforementioned 
ancient Indian paretymologies (such as agni - agräni) and the cases of polyonymy which we shall quote below as examples of asymmetry.

\section{$2 \quad$ Asymmetries as Exceptions}

\section{In Old Indian Sources}

The several passages devoted to paretymological reflections on polyonyms found in the Brāhmana literature (ninth-sixth century BCE) already included the embryo of the opposite thesis. They involve an interesting terminology emphasizing the existence of words "beyond perception" (paro'ksam "out of sight"), which are classified as sorts of synonyms of other immediately comprehensible words (pratyaksam "before one's eyes"). 24

See, for instance, ŚBM 7.4.1.10 (seventh century BCE): átha rukmam úpadadhāti. asau vá,

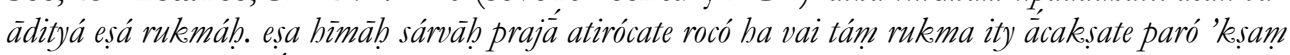
paróksakāmā hi devá amúm evaitád àdityam úpadadhäti

"He [the Sacrificer] puts the gold plate thereon [on the lotus-leaf]. Now this gold plate is the sun, because he shines over all the creatures here on earth; and rocas ('sunshine') they cryptically call rukman ('gold plate'), because the gods love what is 'beyond the perception':25 he thus lays down that sun [on the altar]." ${ }^{26}$

Some lines later, we find a comparison between other features of the plate and the sun, such as their circular shape (parimandala) and golden colour (biranmaya). This means that although, on the one hand, the same or almost the same, shining, round, and gold-coloured object asymmetrically matches the two different nouns which can denote it, on the other, language and reality continue to be intrinsically/naturally linked. A diaphasic option seems to be depicted in these kinds of paretymologies: a human word, which is suitable in a ritual context, has to be replaced in a mythological context, so as to be a part of a divine language:

Tāndyamahäbrähmana 27 22.10.3: yad vai manusyānām pratyakșạn tad devānām parokșam atha yan manusyānām paroksam tad devānām pratyaksam,

"That which is pratyaksa for men, is paroksa for Gods, and vice versa, that which is paroksa for men, is pratyaksa for Gods."

This kind of asymmetry-which is in fact a motivated polyonymy28 - is however presented as a natural feature of the linguistic denotation. It does not matter if the pratyaksa-word is almost a hapax, namely a word which is not ungrammatical but which is not used and has probably been invented merely to explain the paro'ksa word, such as indha- to explain the theonym indra- in ŚBM 6.1.1.1-2:

yad ainddha. tásmād indhah. [...] | [...] indras [...] ity ácaksate paróksam paróksakāmā hí devās [...],

"Since he lights up (indh-), therefore he is indha. [...] Indeed the gods, who love that which is cryptic, cryptically call him indra [...]." 29

Synonymic usages are only systematically prescribed. They are governed by rules, in some specific ritual Soma performances, such as the upabavya, against the background of an almost technical and esoteric setting, ${ }^{30}$ but once again this is a case of a mere opposition between 
a paro'ksa and a pratyaksa signification, and often between a non-explicitly vs. explicitly mentioned summoning of the god to whom the prayers are addressed. ${ }^{31}$

See, for instance, Baudhāyanaśrautasūtra ${ }^{32}$ 18.28: [...] sa yatrāha prātar yāvabhyo devebhya iti marudbhyah prätar yāvabbyo devebhya iti taträha. atha yaträha somah pavata iti induh pavata iti

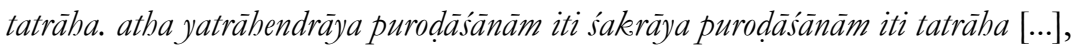

"When [it is to be said] '[do you recite verses] to the gods coming in the morning,' he says 'to the Maruts coming in the morning.' When [it is to be said] 'Soma is flowing (it becomes pure),' he says 'Indu is flowing.' When [it is to be said] 'of the cakes to Indra,' he says 'of the cakes to Śakra' [...]."

See, for instance, Lätyāyanaśrautasütra33 8.9.1-4: upahavye devatānämadheyāni paroksam brüyuh svasthānāsu. pratyaksam asvasthānāsu. devaśabdam sarvatra varjayeyuh. hotā devo mabimitrasyeti botā yajñai mahìajna asyeti brüyur iti somam,

"During the upaharya, they should pronounce the names of the divinities cryptically in their respective places. In places other than their original one, they should pronounce them perceptibly. They should avoid the word deva in all circumstances. In place of the two words deva and mitra in the hotā devo mabimitrasya text, they should say hotā yajñā mahĩyajñasya; instead of soma they should say indu."

Nevertheless, no doubts seem to arise regarding the reliability of both the (perceptible and cryptic) denotations as a valid means of knowledge, since the noun indu somehow depicts a real facet of soma, in the same way as Śakra is a truthful epithet for the god Indra. This particular example of asymmetry is not unmotivated at this step of the reflection on language.

Mylius considers the origin of this tradition as Sāmavedic, based on a sort of foundation myth of this rite, recounted in another Sāmavedic work (Jaiminīyabräbmana [JB] 2.150). ${ }^{34}$ In fact, JB section 2.148-150 is entirely devoted to the explanation of the cryptic upabarya given by Prajāpati to the gods as a sort of weapon against their adversaries. The involvement of original epithets, synonyms, Kenningar, and other stylistic devices tuned to make the comprehension of poetry indirect has been recognized in the earliest sources of several Indo-European languages. Thus, the afore-mentioned Kalpasūtra and Brāhmaṇa explanations of this kind of cryptic usage of language might be the rationalizing (prescriptive or mythic) re-interpretation of the main aim of the ritual-poetic contest. ${ }^{35}$ This might have also consisted in inventing new metaphorical or metonymic designations of the subjects in question, in order to defeat their adversaries and receive the deserved reward from the patron of competitions. ${ }^{36}$ Therefore, such a type of exception to the one-to-one relation between word-forms and their denotations seems to be classified as an option available in the very nature of language itself, even though sometimes it is the mere ephemeral fruit of individual creation.

The most ancient actual discussion on asymmetry is proposed later and ends in favour of its natural encompassment. The relevant section (Nir 1.12-14) is devoted to the specific derivational relation between an action and the matching nomen agentis. The starting point consists in maintaining that nouns are derived from verbs.

Nir 1.12 nāmāny äkhyaatajānīti säakațāyano nairuktasamayaś ca,

"Nouns are derived from verbs according to Sākațāyana and according to the communis opinio of etymologists."

Against this thesis, Nirukta's author (Yāska) quotes Gārgya's restrictive position (Nir 1.12), which excludes primary nouns that cannot invoke a verbal etymon. It limits the extension

Journal of World Philosophies 2 (Summer 2017): 81-108 
of this rule to the mere lexical repertory of derived nouns governed by grammatical rules, such as go "cow," aśva "horse," purusa "person" and hastin "elephant." 37

There are several reasons to argue that Śākațāyana’s thesis has to be refuted. Yāska lists six of Gārgya's objections, ${ }^{38}$ among which three actually pertain to the problem discussed here:

(Nir 1.12) atha cet sarvāny äkhyätajāni nāmāni syur yah kaśca tat karma kuryät sarvam tat sattvam

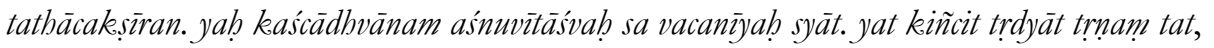
"If all nouns are derived from verbs, each individual who performs a certain action should be called by the same name. Whosoever runs on the road should be called 'runner' (aśva). Whatever pricks [should be called] 'pricker."'

(Nir 1.12) athäpi cet sarvāny akbyātajāni nāmāni syur, yāvadbhir bhävaih samprayujyeta, tāvadbhyo nàmadheyapratilambhah pratilambhah syät. tatraivam sthūnà daraśayà vām samjañ ca syät,

"Moreover, if all nouns are derived from verbs, [each individual] should obtain as many names as the actions with which it is connected. Thus a column should also be 'that which has been fixed in a hole' and 'that on which one hangs (sañj-) [something]."'

(Nir 1.13) athäpi ya eșäm nyāyavān kärmanāmikah samskāro yathā cäpi pratìtārthāni syus tathaināny ācaksîran. purusam puriśaya ity ācaksisiran. aștety aśvam. tardanam iti trnam,

"Furthermore, each grammatical form should be regularly named after the relevant [denoted] action, and these [objects] should be called in such a way that their denotation has to be clearly understood: purusa 'person' should be called puri-saya, lit. 'he who lives in the city,' aśva 'horse' should be called astrt 'he who covers (distances)' and trma 'grass' should be called tard-ana 'that which pricks."”

Yāska's answers are all inspired by the same principle: only linguistic usage has to be taken into account, and no attention should be paid to other sophistries. For instance, the first answer is as follows (Nir 1.14):

paśyāmah samānakarmanām nāmadheyapratilambham ekesām naikesām [...],

"We see that the [performers] of the same actions obtain a single name or not a single name [...]."

Therefore, we can be sure that in Nirukta's age, asymmetry, especially between nomina agentis and the actions which they imply, was a well-known and accepted fact. It was probably considered as a natural part of language, which better emerged when its functioning was analyzed from the synchronic point of view. On the contrary, the actual correspondence between deverbal nouns and the paretymologically linked verbal bases, when it was strictly grammatically governed, ${ }^{39}$ was considered quite obvious and uninteresting, so that the basically supposed oneto-one relation between word-forms and their objects was used as a purely ideal schema.

Therefore, according to the sixth-fifth century BCE testimony supplied by Nirukta, the link between word-forms and their objects can, by nature, also be an asymmetric relation, but it does not depend on artificial rules. In fact, since each object to be denoted is indeed multifeatured, it can consequently be denoted by more than one noun. Thus, the natural meaningform relations are strenuously defended. Three centuries later, Pāninin's commentators seem to be consistent with this perspective. In Kătyāyana's opinion, the linguistic form has to be taken as a whole, rather than by inspecting its single parts. As a consequence each word is sväbhävika "autonomous" ("grounded on its intrinsic conditions"), rather than "conditioned by recognizable factors or causes" (be they external or internal). 


\section{Vt 33 ad A 1.2.64: abbidhānam punah sväbhävilkam}

Vt 15 ad A 2.2.29: abbidhānam ca punah sväbhävikam 40

Both varttikas occur in discussions arising from some difficulty in reconstructing the denotation of a synthetic form by the analytical denotation of its constituents, thus in facing some specific exceptions to the aforementioned linguistic one-to-one relation. For instance, these varttikas explain phenomena such as the occurrence of several objects of the same polysemic word aksa which conveys the sense of "1. axle 2. rosary seed 3. die" or even the denotation of both mother and father, by means of the unique dual form of the noun commonly conveying the single sense "father" (pitarau), or the asymmetry between a root noun and a suffixal noun which share the same role of nomen agentis - cf. baladā- "one who gives strength" vs. kanyä-dätr- "one who gives (a 'giver' of) a daughter in marriage." 41

The unpredictable signification mechanism is explicitly labelled as a natural fact, svabbavilka, autonomous from grammatical rules and ultimately from human efforts. This is similar to Yāska's conclusion when he says: language includes this form and this alone must suffice. More technically, Kātyāyana concludes that the denotation of an inflected word (pada) has to be defined as sväbhävika (independent from its morphs). ${ }^{42}$ Moreover, Patañjali went deeper into the consequences of this detected linguistic mechanism, which, in his opinion, could indeed result in a risky association, if it were purely a conventional matching between objects and the word-forms which can denote them. In other words, the mutual comprehension between speaker and their interlocutor could not indeed be guaranteed. ${ }^{43}$

Thus, Patañjali maintained that a mere grammatical device taken apart from its actual linguistic usage could not ensure a sufficient shared and understandable denotation. Likewise, a rule stating that a cow has to be called a horse and vice versa should be in manifest contradiction with ordinary usage which is consequently so important. Therefore, the symmetric schema of signification might have been evaluated as a sort of basic grammatical convention. This was used in order to easily arrange linguistic knowledge, although grammarians themselves were well aware that the patterns of signification were actually asymmetric by nature. The descriptive pattern of linguistic reality was thus assumed to be basically symmetric, so that a permanent (nitya) relation between the words of the Sacred Texts and their meanings could be taken as granted. Nonetheless, self-evident exceptions had to be admitted and merely registered (on the basis of common usage), though not explained by means of grammar. ${ }^{44}$

\section{In Ancient Greek Sources}

Even if the cultural context as a whole is very different, the development of Greek thought about the word-object relation and about asymmetry—such as polysemy and synonymy—is surprisingly similar to that of Indian culture: both start by considering the word-object relation as biunique and well-established, ${ }^{45}$ but it is subsequently conceived as a human undertaking and as a convention of which the asymmetry is part. As far as the Greek sources are concerned, the aim of the present contribution is to show how these two opposite conceptions developed in presocratic thought. In addition, we would like to demonstrate that they are bound to the problem of language as a means of knowledge, from the first occasional reflections on language in the early literature, ${ }^{46}$ to the more systematic ones of the philosophers and sophists. ${ }^{47}$

The archaic Greek thought on language conceives the word-object relation as responding to a sort of one-to-one principle of correspondence, which presupposes an ontological link between a name and denoted object: names, if well intended, are thus capable of revealing the very nature of things. In fact, archaic sources show that the oldest popular etymologies are the means by which the essence of an object can be revealed through the analysis 
of its name. Although paretymologies find origin in mythological thought, seeing that they were applied from an early age to the names of heroes and gods, they are also the first evidence of a pre-scientific way of thinking about language. The paretymology of the name of A $\sigma \tau v \dot{\alpha} \nu \alpha \xi$ (Hom.

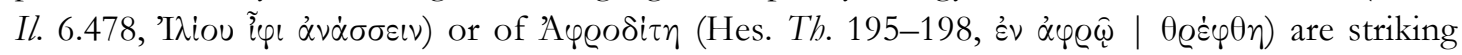
evidence of this. ${ }^{48}$

In the Homeric poems there are some occurrences of double denominations, which can be divided into three types: ${ }^{49}$

1. Double denominations in general (patronymics, double names of animals, objects,

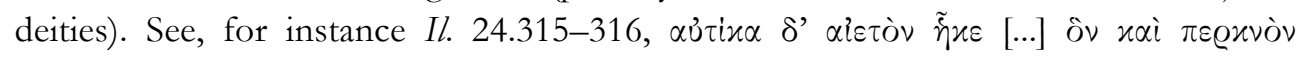

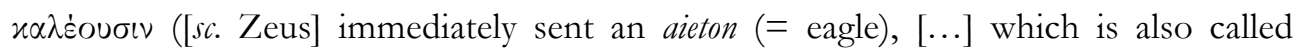
perknos).

2. Different names assigned by deities and by humans. See, for instance Il. 14.290-291,

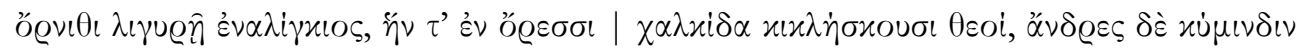
(similar to the singing bird which is in the mountains and called chalkida by the deities and kumindin by humans). 50

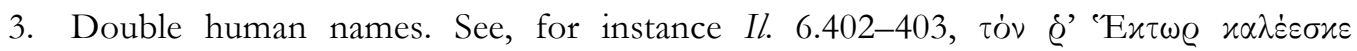

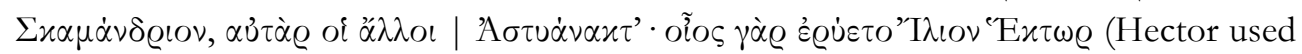
to call him Scamandrion, the others Astuanax, because only Hector defended Ilion). ${ }^{51}$

The last example shows that etymology is used in the Homeric poems to explain one of the two proper names of a human character. ${ }^{52}$ Hesiod uses it to exclusively explain the names of deities and never opposes the names given by gods with those given by humans. ${ }^{53}$ In line with the aim of the Theogony, which tries to put the traditional divine universe in order, Hesiod associates only one name to each deity, as in the case of Briareus and Ino, who, instead, are characterized by two names in the Homeric poems. ${ }^{54}$

The examples quoted above show that the Greeks had already begun to observe the existence of asymmetry in language in the archaic age. If the double denomination involves common nouns, this fact is merely recorded. However, if it involves proper names, it is perceived as particularly anomalous and in need of an explication. This is well exemplified in $f r .7 \mathrm{~B} 1 \mathrm{DK}$ of Pherecydes of Syros, considered by the ancient sources as the author of the first Greek literary text written in prose:

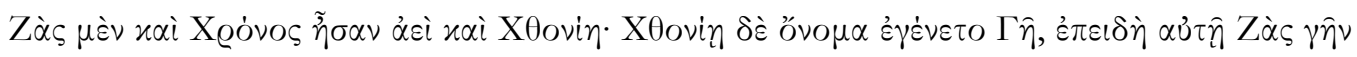

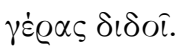

"Zeus, Chronos and Chthonie were eternal; but the name of Chthonie became Ge, because Zeus gave her the earth as an honorific gift."

Pherecydes' aim is to counteract the contradictory idea of the deities who are said to be "forever," but at the same time, "born" (as happens, for instance, in Hesiod) by demonstrating that it is only their name that changes. ${ }^{55}$ He explains Chthonie's new name by means of a paretymology 56 which connects it with her being attributed the domain of the earth. We can also find this kind of justification in the "one deity—two different names-two religious domains" scheme, well exemplified by fr. $116 \mathrm{Kahn}^{57}$ of Heraclitus:

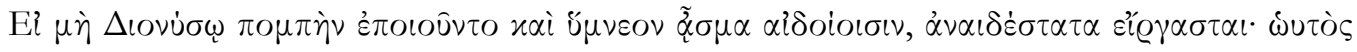

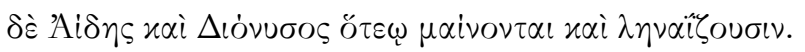

"If it were not Dionysus for whom they march in procession and chant the hymn to 
the phallus, their action would be most shameless. But Hades and Dionysus are the same, him for whom they rave and celebrate Lenaia." 58

The key to this fragment is in its word play. ${ }^{59}$ Aidoi $\alpha$ is connected with $\alpha i \delta \dot{\omega} \varsigma$, which means "shame" but also "reverence." Thus, in this case, the word $\alpha i \delta$ i $\alpha$ denotes the sacred phallic symbols, even if this word also occurs with the denotation of pudenda. Av $\alpha \iota \delta \varepsilon \dot{\sigma} \sigma \alpha \tau \alpha$ is to be intended as the "most shameless actions," but at the same time as $\alpha \nu-\left(^{(}\right)$'A $1 \delta \eta \sigma-\tau \alpha \tau \alpha$. Their actions would be "without Hades" if they were not performed for Dionysus. However, Dionysus and Hades are the same. The verbal connections between $\alpha i \delta o i \alpha-\alpha i \delta \omega \varsigma$ - $\alpha \nu \alpha i \delta \varepsilon \dot{\varepsilon} \sigma \tau \alpha \tau \alpha$ aim to underline the intimate equivalence of Dionysus — the god of vitality through madness-with Aı $\delta \eta$, the god of the underworld, we thus find the equivalence of the two opposites, life and death, in line with the Heraclitean concept of the structure of reality, which consists in the unity of opposites. ${ }^{60}$

In the quoted fragments of Pherecydes and Heraclitus, the polyonymy is recorded, if not as an exception, at least as a particularity: the concept of the adherence of the names to reality is so strong, that it can be assumed that a plurality of names may correspond to a plurality of functions/attributes/domains, but the object is actually only one. Asymmetry is thus justified de facto as only seeming.

Heraclitus introduces us to the field of speculative thought. The ontological bond between names and objects is well attested by some other fragments, such as $f r .123 \mathrm{Kahn:}{ }^{61}$

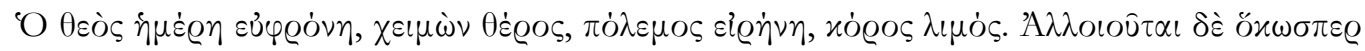

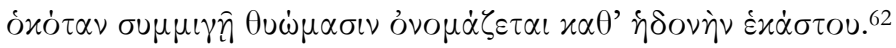

"The god: day night, winter summer, war peace, satiety hunger. It alters, as when mingled with perfumes, it gets named according to the fragrance of each one."

The fragment is the subject of much discussion amongst scholars. ${ }^{63}$ Some of them, such as Kahn and Bollack, and Wismann, maintain the text as attested by Hippolytus (Refut. 9.10.8). However, the majority prefer to follow the correction made by Diels who adds the word $\pi \hat{\mathrm{v}} \varrho$ between ö $\varkappa \omega \sigma \pi \varepsilon \varrho$ and $\delta x \dot{\tau} \tau \alpha \nu .{ }^{64}$ Marcovich has added an ulterior correction: $\pi \hat{v} \varrho$ ò. If this

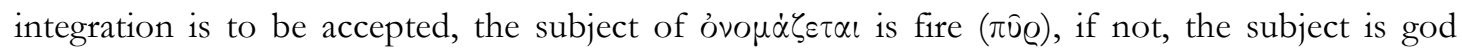

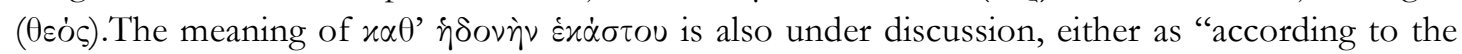
pleasure of each one" or as "according to the fragrance of each $\theta \dot{v} \omega \mu \alpha$," which is the one we prefer. As has been pointed out by Diano and Serra, ${ }^{65}$ following Kirk, and Marcovich, ${ }^{66}$ Heraclitus affirms a real and substantial communion between names and the objects they denote: just as night and day coincide, god is night and day, not as a subject is its predicates, but as different substances are the same and only substance. The one-to-one relationship seems to be confirmed — and the asymmetry relegated to the realm of appearance-in the second part of the fragment, in which the god or the fire changes when mingled with a specific $\theta \dot{0} \omega \mu \alpha$, and its name consequently changes in order to designate each single mixture.

Name and function, conceived as essential and inseparable components of each object, ${ }^{67}$ are equivalent in the well-known fragment $22 \mathrm{~B} 48 \mathrm{DK},{ }^{68}$ which registers a particularly complex example of polyonymia:

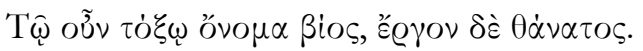

"Then, the name of the bow is life; its work is death."

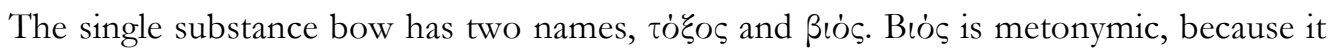
originally designates the bow string and subsequently the bow itself. In fact, Heraclitus is playing 
here with the polysemic value of this word. Considered in its two possible pronunciations, it means 'bow' (ßiós) and 'life' (ßios), and therefore is a contrast in itself: the result of the bow's action is in fact death. Moreover, at Heraclitus' time, the accents of words were not written, and consequently the difference between $\beta$ iós and Bios would not have been immediately perceivable to the reader. ${ }^{69}$

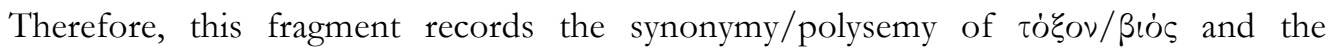
polysemy/homonymy of ßiós/ßios. The object has a double name, but only one effect on reality, which is death. As Robinson has pointed out "the fragment serves also as a striking instance of how names can indicate the reality (or an aspect of the reality) of a thing" (see fragments 23, 32, 67)..$^{70}$

For Heraclitus all things are opposite to each other, creating continuous changes which find their composition in the harmony of the $\lambda \dot{o} \gamma o c$. Ordinary people can only see the opposites, while the sage is the one able to understand the superior harmony and unity which is beyond them: Asós and ßiós are in fact names representing the harmony beyond the opposites. For this reason, even if Heraclitus conceives the word-object relation as one-to-one, he also remarks that (fr. 1 Kahn):

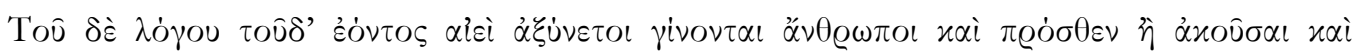

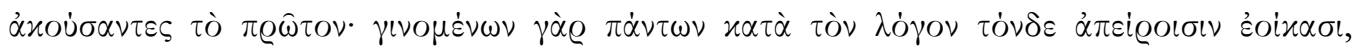

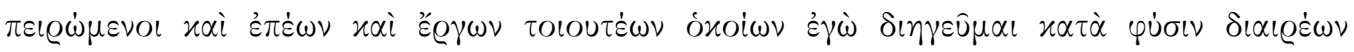

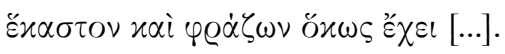

"Human beings are (always) unable to understand this $\lambda \dot{o} \gamma o \varsigma$ which (always) is, both before they have heard about it and while they are hearing about it for the first time. They seem inexperienced in all the things happening according to this $\lambda \dot{o} \gamma o \varsigma$, even if they have experience of the words and the actions such as those I describe according to nature, distinguishing each one and showing how it is [...]."

In this earlier phase of the pre-socratic age, asymmetry was clearly considered a deviation from the intuitively perceived as natural, one-to-one word-object relation, and this led several authors and thinkers to try and justify it, especially by means of etymology. In this age, etymology consists de facto in the search for the thing in the name, and cases of asymmetry, such as the existence of two names for a single deity, must be explained and justified. Thus, we can reasonably conclude that the first answer regarding the nature of this phenomenon is that asymmetry is only seeming. In this frame, Heraclitus can be considered as both archaic and as a starting point. Archaic, because he only conceives the word/underlying égov (the thing) relation and not the one between the linguistic sign and the concept or idea. ${ }^{71}$ However, his work is also an important starting point, since the problem as to whether the word-object relation is naturally

correct or a mere convention actually has its origin in the afore-mentioned search for the "thing" in names, and mostly from the observation of the ceaseless changes of perceivable phenomena. ${ }^{72}$

\section{Asymmetric Signification as a Rule}

\section{In Old Indian Sources}

By contrast, an explicit disbelief in language, considered as an unreliable means of knowledge, also emerges in several Greek and Indian sources where a clear preference for the conventionality of language prevails. Patañjali's Mabäbhäsya (second century BCE) documents this latter 
approach, even though the same work also provides a lengthy commentary on the two glosses, quoted as our starting point on the naturally established one-to-one relationship of signification. The impermanent nature of the objects which are temporarily considered as wholes seems to be emphasized, for instance in M 1.1 1l. 6-7:

atha gaur ity atra kah śabdah. kim yat tat sāsnälängülakakudakhuravisāny artharüpam sa śabdah, "Now, in gaub what is [to be considered] the word? Is it the visible appearance, that which consists in the object possessing dewlap, tail, hump, hoofs and horns? Is this the word?"

Thus, the actually existing objects of language could merely be the constituent parts of the cow and not the whole cow. This interpretation is suggested by the partial coincidence of this perspective on words with a very famous (possibly Sarvastivādin Buddhist) passage, included in a contemporary text, that is the Milindapañba $\left[\right.$ Mil] ${ }^{73}$ (second century BCE). The latter is a work which claims to record a discussion between the king Milinda (supposedly representing the historical Indo-Greek King Menander) and the Buddhist monk Nāgasena. The matching passage questions the real entity of the object denoted by common words such as "chariot":

(Mil 27) nāham bhante nāgasena musā bhañāmi, isañ ca pațicca akkhañ ca pațicca cakekāni ca pațicca rathapañjarañca pațicca rathadạdakañ ca pațicca ratho 'ti saìkhà samañña pañnatti vohāro nämamattam pavattati 'ti,

"Revered Nāgasena, I am not telling a lie: it depends on the pole, on the axle, on the wheels, on the body of a chariot, on the flag-staff of a chariot, on the yoke, on the reins, and on the goad, if 'chariot' exists as a denotation, appellation, designation, as a current usage, as a name."

In fact, as Buddhists unanimously agree, from the ontological point of view, there is no whole independent of its parts, nor indeed do wholes exist at all. Nonetheless, elsewhere (M 1.220 11. 22-4 ad Vt 10 ad A 1.2.45 Vt 10) Patañjali reflects on the whole-part relationship and even employs the chariot example but in a different way. Indeed, he maintains that it is the whole and undivided word that guarantees the denotation and function of the parts, precisely because, only a whole chariot is fit for movement, while its constituents, if they are taken apart one by one (rathängāni vihrtāni pratyekam), are not suitable for this purpose (vrajikriyam praty asamarthāni bhavanti). The linguistic aim is to explain that the combinations (samudāya) of sounds have meaning, whereas the parts do not.

Indeed, this is another way of underlining the intrinsic asymmetry of language, since the autonomous identity of the whole is underlined as a reality which surpasses the sum of its parts. In our example, the chariot is something more than the sum of its parts, which by contrast would be useless if they were separated from each other. Moreover, if we try to proceed by subtraction by starting from the whole, we notice that something which has undergone a change with regard to one of its parts is by no means something else-as a consequence of this change. ${ }^{74}$

Patañjali's mundane example is the case of the classification of animals:

M I.136 11. 9-10 ad A 1.1.56 Vt 10: tad yathā | svā karne vā pucche vā chinne svaiva bhavati nāśvo na gardabha iti,

"When a dog has an ear or tail cut off, it remains a dog indeed. It does not become a horse or a donkey."

Finally, the ontological solidarity between the whole and its parts seems to be insisted upon in the $\mathrm{M}$, with regard to the connection between the linguistic unit and its segments or sub- 
units. One may recognize parts in the dravyas, yet these parts are still intrinsically integrated into the whole, as stated by means of the formula vrksah pracalan sabavayavaih pracalati, "A tree when it shakes, shakes with its parts," which occurs thrice in this work. ${ }^{75}$

Wholes are the permanent frames upon which symmetry is re-established. On the other hand, this pattern opens the way to the well-known difficulty relating to the permanence of words. If words were to lose or modify some of their parts, like a dog losing its ear or tail, they would not be considered as permanent. In fact, grammarians elsewhere tend to resort to the substitution of full words (sarvapadädeśa), in order to avoid what could otherwise appear as "a change, a modification of words." ${ }^{\prime} 6 \mathrm{~A}$ word denoting a whole depends on a convention and warrants the mutual comprehension between speakers in everyday usage, but this kind of word prevents man from grasping the right knowledge.

It seems indisputable that the same question found in the Mil was in the background of Patañjali's reflections on this matter. The relevant examples are closely similar, but the answers are neatly different. For the Buddhist sources, whose pivotal doctrine is the denial of the ontological existence of individual existence, phenomenological individuality is merely admitted as being perceived illusorily, because of temporary combinations (aggregates) of physical and psychic, ultimate and indivisible constituents (dharmas) which are metaphysically a given datum. As a consequence, the impermanent aggregates which illude the human mind are only assumed to exist as names (namadheyamätra). The objects of denotation and the relevant words which denote them are not symmetric, and this asymmetry is tolerated in order to grant conventional communication, i.e. the common mutual comprehension of everyday life.

This conventional use of language is therefore often defended even though it is a recognized obstacle for the true knowledge. For instance, Buddha forbids any transgression of the limits of convention, based on some dialectical usage, as shown in Majjbima Nikayya $[\mathrm{MN}]^{77}$ 3.230 (janapadaniruttim näbbiniveseyya, samañnam nätidhāveyyāti): he is afraid that this can determine verbal incomprehensions or useless disputes, when for example the same object is denoted by different nouns. ${ }^{78}$ The relevant example in MN 3.234-235 is the almost synonymous series of pāli words päti, patta, vittha, saràva, dhäropa, pona, pisilla, used in different parts of the country to denote a "bowl," but more properly matching with a number of different shapes, such as a vessel, a bowl, a cup, a goblet, etc. ${ }^{79}$

Buddha is thoroughly persuaded that there are even words to which no object actually corresponds, such as pāli attan "self" or abam "I," as might be expected, but linguistic convention warrants a mutual comprehension. The example of milk, which changes into curd, butter, and clarified butter and is denoted with a different noun at each stage, shows how the continued use of the same noun khira "milk" instead of the conventional noun denoting the specific states (dadhi, navanita, sappi) is of no help (see Digha Nikāya $a^{80} 1.201$ ). However, none of these nounsthe first one included-actually matches a given existing entity which can be known as such.

In the same perspective of the signification, another point which is shared by the Mabäbhäsya and by the Pāli canon has been highlighted by Bronkhorst in 1987. Throughout the long history of the Buddhist dharma theory, only a limited number of dharmas came to be accepted as truly self-existing entities ${ }^{81}$ and, as is well known, according to the majority of Buddhist schools, their existence is merely momentary. Precisely in order to avoid the judgement of momentariness for sounds, words, and sentences, the Sarvāstivādin School postulatedprobably for the first time-self-existence for two linguistic dharmas, namely the vyañanakajya and the nammakāya/padakāya (sound and word). Patañjali also considers word and sound as the only two self-existing autonomous linguistic entities. ${ }^{82}$ The sole morphological unit which Patañjali consistently considered self-existent is the inflected pada, whose autonomy is never questioned. The different treatment of morphological entities, described in the grammar as somehow originating dependently, reveals the illusory autonomy of sub-units of words-with the 
regular highlighting of the dependence-relationship between morpheme and morpheme in an inflected word or between an inflected word and another one in a compound.

Therefore, the specific linguistic and speculative reflections on the conventional relation between word-forms and their objects, briefly exemplified here, were certainly broadly circulating in India in about the second century BCE. As a result, an explicit adhesion or confutation in the majority of the subsequent technical and speculative traditions could have been requested. Nonetheless, we wonder whether a comparable conventional explanation of the asymmetry of language was also advanced earlier, because the relevant Buddhist sources date back to at least the second century BCE, although it is possible that they constituted some portions of Buddha's preaching (thus dating back to sixth-fifth century BCE).

Indeed, in the Chandogya-Upanisad [ChUp], ${ }^{83}$ which possibly dates back to the sixth century BCE, language is in fact presented as a human undertaking that creates specific distinguished objects and fashions reality into its illusory discrete entities:

ChUp 6.1.3-4: [...] katham nu bhagavah sa ädeśo bhavatïti. yathä somyaikena mrtpindena sarvam mrnmayam vijñätam syāt. vācārambhanam vikāro nāmadheyam mrttikety eva satyam,

“[...] How indeed does this specific teaching ${ }^{84}$ work, sir? Dear, as everything made of clay, could be discerned by means of just one lump of clay, the specific modified form is a verbal undertaking, ${ }^{85}$ a name: the perceptible reality is just this: 'It's clay."'

ChUp 6.4.1-2: yad agne robitam rüpam tejasas tad rüpam. yac chuklam tad apäm. yat kerșnam tad

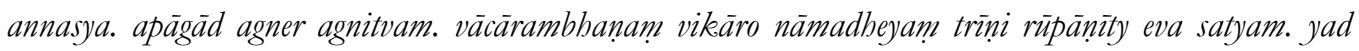
àdityasya rohitam rüpan tejasas tad rüpam. yac chuklam tad apām. yat kersnam tad annasya. apāgäd

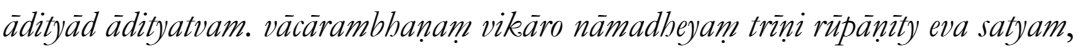

"The red visible appearance of fire is indeed the visible appearance of energy; the white, that of water; the black, that of food. The individuality of fire disappears. The specific modified form is a verbal undertaking, or better a name. ${ }^{86}$ The perceptible reality is just this: the three visible appearances. The red visible appearance of the sun is indeed the visible appearance of energy; the white, that of water; the black, that of food. The individuality of the sun disappears. The specific modified form is a verbal undertaking, or better a name. The perceptible reality is just this: 'They are just the three visible shapes."”

The sapiential and substantially gnostic context of these passages aims at going beyond the discriminatory knowledge (viveka-jñana) which is a condemned fruit of ignorance. In fact, it illusorily generates the plurality of perceptible appearances, which all prevent the common people from catching the ultimate oneness of truth (more precisely of that which is permanent, namely that which is ontologically/metaphysically really existent). Therefore, differently from the Mil passage quoted above, the aim here is to show that the shapes and names (rüpa and naman) of things cannot be real, because the imperceptible one is the only substance that exists. The three basic evolutes mentioned-termed here as energy, water, and food-especially because they explicitly match the colours of red, white, and black respectively, might be considered as a sort of antecedent of the well-known three properties (gunas) of the Samkhya tradition-the three qualities of primeval, irreducible, and immanifest matter (nature). The temporary individualities which language provides with labels/names depend on the different mingling of these three properties, but the only ones that actually (ontologically) exist are these three basic properties of nature.

The shared point is that if language did not provide these temporary combinations with proper designations, they would not be perceived at all. The multiplicity of commonly used 
nouns is thus massively asymmetric with respect to reality which is one (or threefold at the most). As a consequence, this perspective does not have so much confidence in language as a valid means of knowledge, which is reasonably judged responsible (guilty) for the deception of the ignorant and prevents them from perceiving that which really exists beyond the phenomena. By contrast, this asymmetric conventional relationship between language and reality is a crucial medium of communication, the awareness of which — and consequently the highlighted second approach to linguistic asymmetry — seems to be supposed as having circulated for a long time and contemporaneously with the previously described approach (asymmetry as a mere natural exception to the broadly extended symmetry), perhaps at least between the sixth and the second BCE.

\section{In Old Greek Sources}

In the Greek culture, Parmenides is the first to explicitly declare that names have been imposed by humans (fr. 28 B 8 DK, 11. 38-40). Thus, we suppose that he does not believe that language merely arises by nature.

$T \hat{\omega} \pi \dot{\alpha} \nu \tau^{\prime} \not \partial v o \mu(\alpha)$ है $\sigma \tau \alpha$,

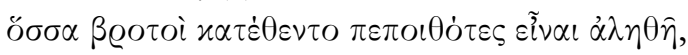

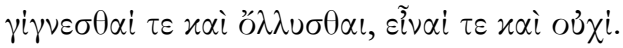

"The being will have as many names,

as those which have been imposed by the mortals, who are convinced

that they are true: 'to be born,' 'to die,' 'to be' and 'not to be.'

According to Parmenides, the being is immobile, eternal, one and whole. However, human beings are deceived by opinion $(\delta \dot{\delta} \xi \alpha)$, which makes reality appear as divided into different components, so that humans have imposed names in order to identify each of them $(f r$. 28 B 19 DK):

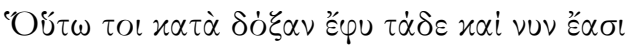

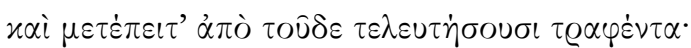

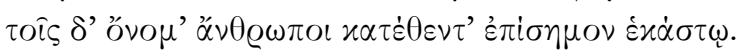

"In this way, according to opinion, these things are born and now are, then, once they have grown, they will die:

humans imposed names as distinctive signs of each one."

Unlike Heraclitus, for whom the óvó $\mu \alpha \tau \alpha$ are only nouns, Parmenides evidently thinks that they are also verbs and locutions. Both philosophers think that humans are deceived by the seeming multiplicity of reality, but only Parmenides explicitly states that they have imposed names on each part of it, so that it is clear that he conceives these names as a mere convention. According to this conception, asymmetry, which is once again identified with polyonymia, seems to be a consequence of the deceitful knowledge of reality.

As far as Empedocles is concerned, the structure of the world is made up of four simple, eternal, and unalterable elements—earth, fire, air, and water-which are brought into union by Love and into separation by Strife (fr. 31 B 8 DK):

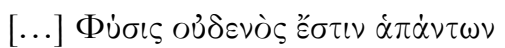

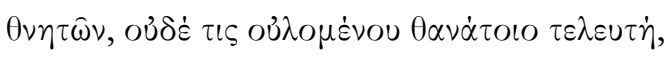

$\dot{\alpha} \lambda \lambda \dot{\alpha} \mu \dot{O} v o v \mu i \xi \iota \varsigma \tau \varepsilon \delta i \dot{\alpha} \lambda \lambda \alpha \xi i \varsigma \tau \varepsilon \mu l \gamma \varepsilon \dot{\varepsilon} \tau \omega \nu$

Journal of World Philosophies 2 (Summer 2017): 81-108

Copyright (C 2017 Valeria Melis and Tiziana Pontillo.

e-ISSN: 2474-1795 • http://scholarworks.iu.edu/iupjournals/index.php/jwp• doi: 10.2979/jourworlphil.2.1.07 


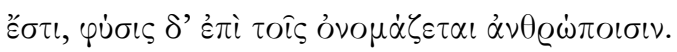

" [...] There is neither birth for anyone of the mortals, nor death destroying them,

but what exists is only the blending and the separation of the mixed elements, even if it is called 'birth' by humans."

This fragment clearly shows that nominating is a human prerogative. ${ }^{87}$ Fr. $31 \mathrm{~B} 9 \mathrm{DK}, 11$. $3-5$ (= fr. 56 Bollack) is even clearer about the matter. When the elements are mixed in the form of man, animals, plants or birds

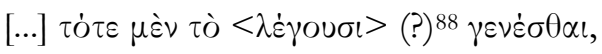

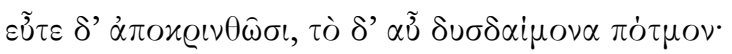

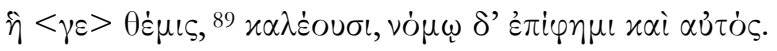

"[...] then they call it 'to be born,'

but when they separate, they call it 'unfortunate fate';

surely, they call it with good reason, and I myself agree with this custom."

While Parmenides condemns names as manifesting the lack of understanding of reality, Empedocles accepts them as a useful convention for communication between humans, provided that they recognize the true structure of the world lying beyond them. In his opinion, even if reality is made up of momentary aggregations, humans can communicate with each other by giving names to each group. The norm provides for the reparation of a natural asymmetry between the names — which are stable and fixed by a convention—and the object they refer towhich is only seemingly unitary.

According to Proclus, Democritus explicitly discusses the arbitrariness of names by means of four arguments (fr. 68 B $26 \mathrm{DK})$ :

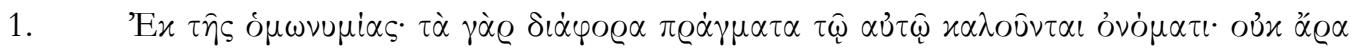

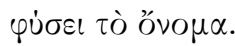

"The proof from homonymy: different objects are called by the same name; hence names do not exist by nature." 90

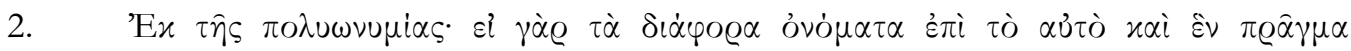

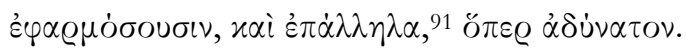

"The proof from multiple names: if different names refer to one and the same object, they also refer to each other, which is impossible."

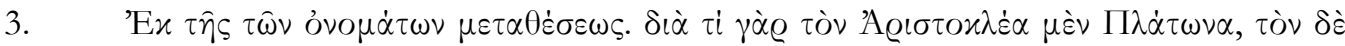

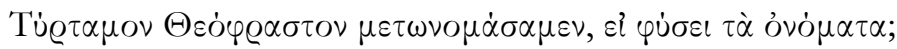

"The proof from changes of names: why did we change the name of Aristocles to Plato, and Tyrtamus to Theophrastus, if names exist by nature?"

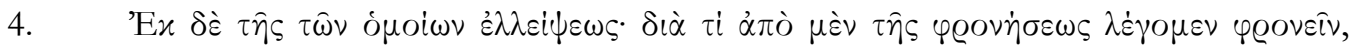

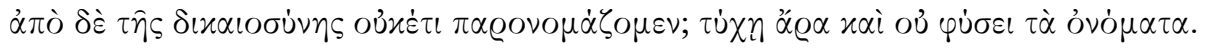

"The argument from the lack of corresponding names: why do we derive 'being wise' from 'wisdom,' but from 'justice' we have no verb? Hence names exist by chance and not by nature." ${ }^{92}$ 
Democritus thus sheds light on the lack of a perfect correspondence between language and reality. 93

According to the sources, the sophist Protagoras considers both the theories of Democritus and the doctrines about the ceaseless changes of the universe, expecially the one proposed by Heraclitus.94 The latter doctrine surely underlies the Protagorean theory of relativism, according to which "of all things the measure is man, of things that are that they are, of things that are not that they are not" (Pl. Tht. 152a. Tr. Graham). If man is the measure, everything he experiences or says is true: as a consequence, two opposed discourses on the same matter are equally true. Plato and Aristotle link Protagoras to the eristic for his attempt to refute the speeches of his antagonists by exploiting the ambiguities of words. ${ }^{95} \mathrm{He}$ also treats the lack of correspondence which may exist between the 'natural' and the grammatical gender of names, blaming, for example, the use of names such as $\mu \bar{\eta} \nu \varsigma_{\varsigma}$ 'anger' or $\pi \dot{\eta} \lambda \eta \xi \xi$ 'armour' as feminine rather than as masculine. 96 The scholars agree on the fact that Aristophanes puts this kind of Protagoraean research to shame in his Clouds, where Socrates notes that both the rooster and the hen are called with the masculine $\alpha \lambda \varepsilon \varkappa \tau \varrho v \dot{\omega} \nu$ in Greek. It is, thus, necessary to coin a new feminine name, such as $\dot{\alpha} \lambda \varepsilon \varkappa \tau \varrho \dot{\alpha} \alpha \mathbf{v} \alpha$ ! Moreover, even though the name of the kneading-trough, $\dot{\eta}$ $x \dot{\alpha} \varrho \delta o \pi \circ \varsigma$, is feminine, it belongs to the o-stem declension which is usually assigned to masculine names (658-680). An echo of the Protagorean research was also seen in the so-called 'battle of the prologues' in Frogs 1119-1197,97 where it is however possible that in lines 1182-1195, Aristophanes is alluding to Prodicus' 'correctness of names' theory. ${ }^{98}$

In fact, Prodicus, said by the Suda to be the "disciple of Protagoras," 99 deals with the socalled ỏ $\theta \dot{o} \tau \eta \varsigma \tau \hat{\omega} \nu \dot{o} v o \mu \dot{\alpha} \tau \omega \nu .{ }^{100} \mathrm{He}$ was interested in etymology ${ }^{101}$ and in homonymy, ${ }^{102}$ even if most sources inform us about his research on synonymy. This is where Prodicus shows that words commonly considered as having the same object are not completely interchangeable. Plato's Protag. 337a-c might show Prodicus' method, which consists in considering two synonyms and in explicating the reason why they are actually (even if sometimes only slightly) different:

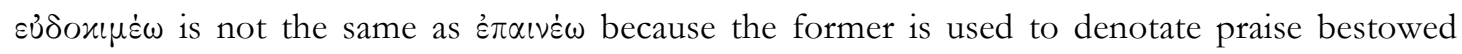
without any deceit, while the latter should also indicate insincere praise.

We agree with Mayhew's opinion that Prodicus probably thinks that names are "stipulated (and so in an important sense conventional), but that it helped if they could be derived from or connected to the nature of what they name." 103 Protagoras and Prodicus are a step ahead of Empedocles. He accepts the conventionality of names as a useful means for

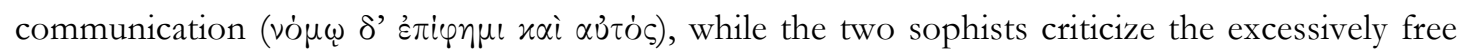
use of words, which should adhere to the denoted object with precision. Playing with ambiguities is in fact the best way to deceive, but also to be deceived.

One of the most famous sophists, Gorgias, sheds light on the impossibility for words to convey knowledge of things, because they are of a completely different nature (fr. $82 \mathrm{~B} 3 \mathrm{DK}$, SS 83-87):

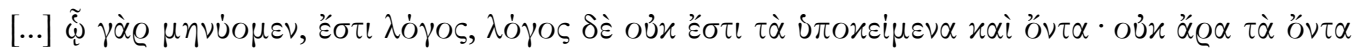

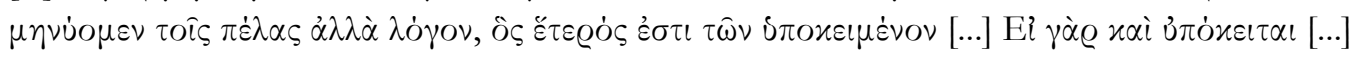

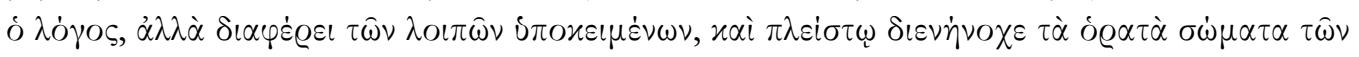

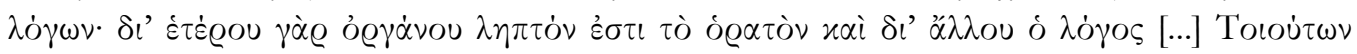

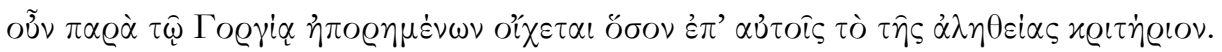

"[...] That by which we communicate is speech, but speech is not the subsisting and existing things themselves. Therefore we do not communicate to our neighbours the existent things, but speech, which is different from the subsisting things [...] Even if speech does subsist, it differs from other subsisting things, and visible bodies differ most markedly from words. For the object of sight is grasped by a different organ than speech 
[...] Since such things are called into question by Gorgias, as far as they are concerned the standard of truth fails." 104

The awareness of the instability of the perceivable phenomena, which had just begun with Heraclitus, brings thinkers, such as Parmenides and Empedocles, to recognize the conventional status of words and the instability of the word-object relation. Gorgias develops this assumption by asserting that it is not possible to know reality by means of words. In this second phase of pre-socratic thought, the word-object relation is thus considered as a mere convention. A well-established and naturally one-to-one correspondence between word and object does not exist, and this is also the reason why asymmetry exists with no exception. ${ }^{105}$

\section{Conclusions}

The comparative analysis of Indian and Greek traditions clearly shows that both followed the same iter which led from the intuitive belief in a natural one-to-one word-object relation to the conviction that this relation is a mere convention and a human undertaking. This conclusion is strictly bound to the observation of the ceaseless change and instability of reality. Thus, asymmetry is at first considered as only seeming, and the role of language as a means of knowledge is preserved; subsequently, the existence of asymmetry is recognized and accepted as part of the convention on which language is based. The consciousness of the lack of a wellestablished and natural word-object relation led to the conclusion that language is definitively an unreliable means of knowledge.

In both India and in Greece, paretymologies play the role of checking the one-to-one word-object relation. This is mostly applied to divine names, as shown by the passages from Rgveda, Atharvaveda and the Nirukta, and in those by Homer, Hesiod, Pherecydes of Syros, and Heraclitus.

In both the selected groups of sources, the reflection about asymmetry encompasses the thought on the almost technical derivation of words. Compelling evidence of this is offered by some examples from the Nirukta, on the one hand, and from Democritus, on the other.

In the passages from the Vedic Upanișads and the Buddhist sources, language is presented as a human undertaking, which determines the deception of the ignorant. The latter erroneously concentrates on whole objects and their matching nouns instead of on their single perceptible parts and is prevented both from perceiving that which really exists beyond phenomena and from having access to the phenomena as such (dharmas). This kind of speculation, particularly the Upanișadic one, perfectly matches the thought of Parmenides and Heraclitus, who are convinced that the majority of people are not able to comprehend reality beyond the multiplicity of phenomena on which names are usually imposed. The Buddhist sources tolerate the asymmetry between the objects of the denotation and the relevant words, exactly as Empedocles does, in order to warrant the mutual comprehension of speakers.

The most important difference between the two cultures, as emerges from these documents, is that a technical-grammatical reflection on language was developed earlier on in India. Therefore, the watershed in the development of Indian reasoning on word-signification is the work of genuine linguists, such as Pānini (fourth century BCE) and his first commentators (third-second century BCE). On the contrary, as far as Greek sources are concerned, we are forced to merely adopt the general distinction between thought before and after Socrates.

Nonetheless, both in the ancient Greek sources and in the most ancient Indian ones such as the Vedic passages here quoted, in the period considered here (respectively, mid eighth century BCE-fifth century BCE and twelfth century BCE-fifth century BCE), language is not the

Journal of World Philosophies 2 (Summer 2017): 81-108 
specific object of interest and those who reflect on it are often not grammarians. As a consequence, linguistic phenomena are at first occasionally observed in literary texts, and only later do they become part of technical traditions and of wider philosophical theories about the structure of the world. It is also noteworthy that it is only in India that linguistic theories are mostly influenced by the need to preserve the validity of the ritual ${ }^{106}$ and the permanent relation between the words of the sacred text and the objects they refer to.

It is reasonable to assume that the abovementioned specific need is also sufficient justification for the frequent primacy of speculations on language in the subsequent scientific and technical Indian scenario. It is documented at a very early date in the Nighantu's exegetical-lexical lists (commented on by the Nirukta), which, as is well-known, are mainly arranged according to the categories of synonyms, homonyms and theonyms, thus according to the asymmetries of language. This system seems to presuppose the crucial concept of substitution, ${ }^{107}$ which may already have played a decisive role in the ancient Vedic ritual-poetic contest in assuring preeminence in the sacrificial arena and as a consequence in society. Later the substitution considered as "a theory of truth" (Kahrs 1998: 173) became the focus of the majority of philosophical assertions in Upanișadic thought, by means of the so-called "equivalences," which are often pondered substitutions of objects or concepts with others considered equivalent. To a large extent, this system of "replacement" could be considered as a peculiarly Indian and ritually oriented development of the wide potentialities of asymmetry.

Instead, in Greece the problem of asymmetry was almost always strictly linked to that of the reliability of the words and of the $\lambda \dot{o} \gamma o$ they make up. This relation was historically decisive both in the field of rhetoric intended as art of persuasion, especially in political and legal contexts, and in that branch of philosophy which investigates the possibility of knowing reality by means of logical reasoning. 108

Valeria Melis gained her $\mathrm{PhD}$ at the University of Turin with a thesis on "Traces of Sophistic and Juridical Debate in the Orestes of Euripides." She is author of contributions mainly focused on Euripidean drama ("Eur. Hel. 255-305 e l'Encomio di Elena di Gorgia: un dialogo intertestuale," Lexis 34, 2016, pp. 130-143; "Eur. Hel. 286: un nuovo contributo esegetico," Lexis, 33, 2015, pp. 183-194; "La crisi del concetto democratico di vómos nei vv. 485-489 dell'Oreste di Euripide," in ed. R. Angiolillo, E. Elia, E. Nuti, Crisi. Immagini, interpretazioni e reazioni nel mondo greco, latino e bizantino, Atti del Convegno Internazionale Dottorandi e Giovani Ricercatori, Torino 21 st-23 $3^{\text {rd }}$ october 2013, Edizioni dell'Orso, Alessandria, 2015, pp. 9-22; "La condizione di Oreste tra sacro e profano: un istituto giuridico nascosto. Eur. Or. 512-517, IG I ${ }^{3}$ 104, 11. 26-29," in ed. A. Busetto, S.C. Loukas, Ricerche a Confronto. Dialoghi di Antichità Classiche e del Vicino Oriente, Bologna - Rome Tre - Turin 2012, Edizioni Saecula, Zermeghedo (Vi), 2015, pp. 171-182, 190-191; "La maladie d'Oreste: réalité et apparence entre sophistique et littérature médicale. Eur. Or. 235 sqq.," in ed. M.L. Desclos, Actes du Colloque "La Poésie Dramatique comme Discours de Savoir. Le Problème de la Réappropriation par la Philosophie des Discours de Savoir Antérieurs," Grenoble - UPMF - 21-22 May 2015, Classiques Garnier, Paris [forthcoming]). She is also author of a contribution on the Argonautica of Apollonius Rhodius: "La prova di Giasone nelle Argonautiche. Rilettura di un mito nell'ottica di un poeta alessandrino" (GAIA, 15, 2012, pp. 211-223). She is currently carrying out her research at the University of Cagliari.

Tiziana Pontillo is Associate Professor (Sanskrit Language and Literature/ Indian Religions and Philosophies) at the Philology, Literature and Linguistics Department of Cagliari University, Italy (2002-2015 Lecturer). She gained her PhD with a thesis on Pānini's Zero-Morphology (Milan 2000). Author of about ninety contributions, mainly on technical (grammatical, ritual and rhetoric) Sanskrit Literatures, such as "Where the sense is intended although the corresponding 
speech unit is not employed": the ekaśesa case" (15th World Sanskrit Conference, Delhi 2012, D.K. 2013), "The yugapad-way of using words: how a linguistic taboo became a crucial literary strategy" (Lingua Posnaniensis 2013: ICOSAL, Moscow 2012), and (co-authored with Elisa Freschi) Ruleextension strategies in Ancient India (Peter Lang 2013). Co-editor with Maria Piera Candotti of Signless Signification in Ancient India and Beyond (Anthem 2013). She was project-leader at Cagliari University for the RAS/U.E. Research 'Traces of a 'heterodox' concept of kingship in ancient, medieval and modern India" (2013-2015), in the contest of which she was the editor of the Proceedings of the Conference "Patterns of Bravery. The Figure of the Hero in Indian Literature, Art and Thought, Cagliari 2015," in Indologica Taurinensia XL and co-editor (with M. Dore and H.H. Hock) of "Vrātya Culture in Vedic sources," DK: New Delhi/Bangkok 2016 (Proceedings of a 16 th World Sanskrit Conference Panel, Bangkok 2015).

This paper is a joint work discussed and shared in its entirety by both authors. Valeria

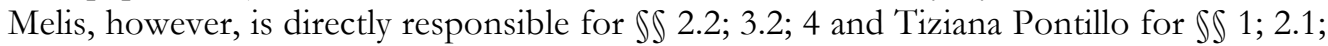
3.1. We wish to thank Elisa Freschi and Patrizia Mureddu for their insightful suggestions regarding a draft version of this present paper, and Maria Piera Candotti for allowing us to repropose here the results of several joint inquiries (see bibliographic references). We are also sincerely grateful to our two anonymous reviewers for their precious corrections and comments. Of course, the responsibility for any mistakes lies solely with us. All translations are the authors', unless explicitly stated.

1 This principle has been singled out by Bronkhorst. See Johannes Bronkhorst, "Sanskrit and Reality: The Buddhist Contribution," in Ideology and Status of Sanskrit: Contributions to the History of the Sanskrit Language, ed. Jan E. M. Houben, (Leiden: Brill, 1996), 109-35; Id., "The Correspondence Principle and Its Impact on Indian Philosophy," Indo-Shisôshi Kenkŷu 8, (1996): 1-19; Id., Language et réalité: sur une épisode de la pensée indienne (Turnhout: Brepols, 1999); Id., Language and Reality: On an Episode of Indian Thought (Leiden: Brill, 2011); Id."“The Correspondence Principle and Its Critics," Journal of Indian Philosophy 41, (2013): 491-99.

2 Pānini's grammar probably dates back to fifth century BCE: the varrttikas ("short glosses") on this grammar are attributed to Kātyāyana; the first commentary on Pāninin's grammar, i.e. the Mabābhāsya, was composed by Patañjali, who possibly lived in the third and in the second century BCE respectively.

3 For the poetic-rhetorical outcomes of this general rule see Tiziana Pontillo, "The yugapad-Way of Using Words, i.e. How a Linguistic Taboo Became a Crucial Literary Strategy," in Proceedings of the International Conference on the South Asian Languages and Literatures, Moscow, 5-7/07/2012, ed. Alice Davison, Hans H. Hock, Liudmila Khokhlova, "Lingua Posnaniensis" 55, 2, (2013): 109-22.

$4 \quad \mathrm{M}$ and Vt are quoted from: The Vyäkarana-Mahäbhäshya of Patañjali, ed. Franz Kielhorn, 1880-1885, Third edition, Revised and Furnished with Additional Readings, References and Select Critical Notes by Kashinath V. Abhyankar (Pune: Bhandarkar Oriental Research Institute, 1: 1962; 2: 1965; 3: 1972 [3 vols.]).

5 A is quoted from The Astāadhyāỹ of Pānini, ed. and trans. Rama N. Sharma (Delhi: Munshiram Manoharlal, 1990-2003 [5 vols.]).

6 A 1.2.64: sarüpānàm ekaśesa ekavibhaktau, "A single remainder of [many] items having the same form occurs, provided that a single ending is used." A proposal for considering this rule as an exception to the one-to-one symmetry between word-forms and their denotation, to be interpreted as a substitution-rule, is advanced in Tiziana Pontillo, "Where the sense is intended although the corresponding speech unit is not employed': the Ekasiesa case," in Proceedings of the 15th World Sanskrit Conference, Delhi 5-10 January 2012 (Vyākaraṇa Session), ed. George Cardona (New Delhi: D. K. Printworld, 2013), $97-132$. 
In the Pāninian tradition, artha, as a linguistic term, does not denote the meaning as a concept, but clearly denotes the object on which a word-form "falls," i.e. the referent - cf. Jouthe A. F. Roodbergen, Dictionary of Pāninian Grammatical Terminology, s.v. (Pune: Bhandarkar Oriental Research Institute, 2008). In particular, Kātyāyana and Patañjali consistently use almost "pragmatic" examples, in order to check the functioning of language. See e.g. M 1.250 1l. 20-25 ad A 1.2.68, 70 and 71 Vt 2 where it is noted that when someone says "Bring the brother" (bhrätā nìyatäm) in everyday usage, one's sister is not brought (na hi [...] svasā nīyate). Even though the relation between a word and its referent is considered primordial-Mìmāmsāsūtra 1.1.5: autpattikas tu śabdasyārthena sambandhạ [...]—-see Śrimajjaiminipraṇite Mimāmsādarśane: MimāmsakakanthiravaKumārilabhattapranita-Tantravārtikasahita-Sáabarabhāsyopetah, ed. Kashinath V. Abhyankar, and Ganesasastri A. Jośî (Poona: Anandasrama, 1971-1980 [1929-1934]), it is only in the Mīmāṃsaka tradition that "knowing a language (being linguistic) involves much more than simply 'knowing the names for things'; it involves, much more basically, having a grasp of the meaning of meaning" (Arnold 2006: 476). See Dan Arnold, "On Semantics and Samketa: Thoughts on a Neglected Problem with Buddhist Apoha Doctrine," Journal of Indian Philosophy 34, (2006): 415-78.

8 This passage constitutes the very first varttika by Kātyāyana in Kielhorn's edition of the $\mathrm{M}$ and it becomes a general presupposition for later linguistic reflection. Even Nāgeśa Bhatța (1730-1810) still relies on this relation (sambandha), more precisely between an inflected word (pada) and its referent, in order to define the signifying "power" or "capacity" (sakti) of language.

9 In other words, Pānini, along with each user of his grammar (who should be a quite good speaker of the Sanskrit language, on the basis of Houben's reflections) is supposed to know in advance which words of everyday language have to be used. See Jan E. M. Houben, "'Meaning Statements' in Pânini's Grammar: on the Purpose and Context of the Astâdbyâyi," Studien zur Indologie und Iranistik 22, (1999): 23-54. Furthermore, it is presupposed that grammar neither produces words nor teaches their meaning. In fact, all correct language is independent of grammarians. See M 1.7 1. 28-8 1. 1 where a grammarian's job is compared with that of a potter.

10 Both Kashinath V. Abhyankar, and Jayadev M. Shukla, Patañjali's Vyäkarana-Mahābhāsya. Áhnikas 1-3. With English Translation and Notes (Poona: Bhandarkar Oriental Research Institute, 1975), and Shivram D. Joshi, and Jouthe A. F. Roodbergen, Patañjali's Vyākarana-Mahābhāsya. Paspaśāhnikea (Poona: University of Poona, 1986), divide this varttike into three parts, since Patañjali comments on the relevant three strings separately. With regard to the place occupied by this first varttika and its supposed author, see George Cardona, Recent Research in Pāninian Studies (Delhi: Motilal Banarsidass, 2004 [1999]), 223-25.

11 Of course, this analysis of sabdarthasambandhe as a tatpurusa-compound does not match Patañjali's interpretation-see e.g. Peter M. Scharf, The Denotation of Generic Terms in Ancient Indian Philosophy: Grammar, Nyāya, and Mìmāmsā (Philadelphia: American Philosophical Society, 1996), 22. In fact, Patañjali's analysis as a samāhāra dvandva implies a more compelling interpretation as "words, meanings and [their] relations," but this seems to contradict the current use of varttika. See Joshi, and Roodbergen (1986: $90 \mathrm{n}$. 331); Madeleine Biardeau, Théorie de la connaissance et philosophie de la parole dans le brahmanisme classique (Paris: Mouton, 1964), 36; Jan E. M. Houben, The Sambandhasamuddésa (Chapter on Relation) and Bhartrhari's Philosophy of Language 37 (Gröningen: Egbert Forsten, 1995), n. 59. Furthermore, Patañjali glosses siddha as nitya ("permanent"), while nitya is commonly attributed to a linguistic form (nitya vs. kärya). This is the only occurrence, out of almost 150 occurrences of the term, where it refers instead to the object meant by a word. See Maria Piera Candotti, and Tiziana Pontillo, "The Autonomous Process of Denotation: Kātyāyana and Patañjali on the Limits of Analysis," in Tìrthayātrā. Essays in Honour of Stefano Piano, ed. Pinuccia Caracchi, Antonella S. Comba,

Journal of World Philosophies 2 (Summer 2017): 81-108 
Alessandra Consolaro, and Alberto Pelissero, (Alessandria: Edizioni dell’Orso, 2010), $41-61$.

12 It finally depends on the intention of making something known, i.e. of conveying some meaning through a verbal expression.

13 Cf. Johannes Bronkhorst, Three Problems Pertaining to the Mahäbhäsya (Poona: Bhandarkar Oriental Research Institute, 1987), 40. contra the hypothesis that according to Patañjali, a word is a mental or psychical entity. For further reflection on this feature of the signification and some comparable passages from/in Bhartrhari, see Maria Piera Candotti, and Tiziana Pontillo, "The Earlier Pāninian Tradition on the Imperceptible Sign," in Signless Signification in Ancient India and Beyond, ed. Tiziana Pontillo, and Maria Piera Candotti (London, New York, Delhi: Anthem Press, 2013), 129-30.

14 See Max Deeg, Die altindische Etymologie nach dem Verständnis Yaska's und seiner Vorgänger (Dettelbach: Röll, 1995). For the assumption of a rhetoric and narrative scope of these technical figures of speech, see also Hans Schmeja, Interpretationen aus dem Rgveda (Innsbruck: AMOE 1987) and Tiziana Pontillo, "Can the So-called 'Identifications' be Included Among the Narrative Techniques of the Late Vedic Literature?" in Proceedings of the International Seminar on Narrative Techniques in Indian Literature and Arts - University of Calicut 7-9 January, 2010 (New Delhi: Department of Sanskrit, University of Calicut, 2012), 7-20.

$15 \mathrm{RV}$ is quoted from Rgveda-Sambitā with a Commentary of Sāyanāāarya, ed. Nārāyana Ś. Sontakke, and Chintaman G. Kashikar (Poona: Vaidika Saṃśodhana Maṇdala ${ }^{21983}$ [1933-1951; 4 vols]).

Atharvaveda (Śaunaka) with the Padapätha and Sāyanāaārya's Commentary, ed. Vishva Bandhu (Hoshiarpur: Vishveshvaranand Vedic Research Institute, 1960-1962).

Cf. AVŚ 9.5.13 ab.

Cf. e.g. RV 6.16.48; AVŚ 18.1.27-28.

Nir is quoted from The Nirukta of Yäska (with Nighanțu), Edited with Durga's Commentary, ed. Hari M. Bhadkamkar (Poona: Bhandarkar Oriental Research Institute, 1985).

20 For the several steps of this specific kind of Vedic exegesis which crucially relies on paretymologies and other technical devices, see Eivind Kahrs, Indian Semantic Analysis. The Nirvacana Tradition (Cambridge: Cambridge University Press, 1998).

21 Nevertheless, the verbal noun in -ana is one of the canonical technical methods Yāska uses to explain which is the verbal base from which a noun is supposed to derive. See the complete list of these methods in Eivind Kahrs, "Yāska's Nirukta: the Quest for a New Interpretation," Indologica Taurinensia 12, (1984): 139-54.

22 We read the same phrase twice in the RgVeda: RV 1.103.2ab; RV 2.15.2cd. And there are at least 4 other RV occurrences and 1 AVŚ occurrence of the same connection with the verb prath-: RV 5.58.7; RQV 6.72.2; RQV 8.89.5; ṚV 10.82.1; AVŚ 12.1.2; AVŚ 4.26.1. Cf. also RV 1.55.1ab and Śatapathabrähmana (Mādhyandina Recension) [ŚBM] 6.1.1.15; 6.1.3.7, where Prajāpati is the agent of the action of prath-. ŚBM is quoted from The Satapatha-Brähmana in the Mādhyandina-säkhā with Extracts from the Commentaries of Säyana, Harisvämin and Dvivedagainga, ed. Albrecht Weber (Varanasi: Chowkhamba Sanskrit Series Office 1964 [1885]).

23 This term is merely used here in a pre-classical sense, namely in accordance with the late Vedic lexicon: see the Brāhmanna-passages quoted below (\$2.1), in which pratyaksasa"before one's eyes" is opposed to paro'ksa- "out of sight."

24 For the story of this terminology and its relation with the technical tradition, in particular with Durga's commentary on the so-called three principles of the Nirukta, see Tiziana Pontillo, "Il Paroksa come oggetto delle etimologie (del Nirukta e dello ŚatapathaBrähmana)," Rendiconti dell'Istituto Lombardo. Accademia di Scienze e Lettere (Lett.) 128, (1994): 
1-19; Ead., "Parole poliseme nel Nirukta," Annali di Cà Foscari 33, 3, (1994), s. orient. 25: 303-09; Ead., "Etimologie nel Nirukta e nello Śatapatha-Brāhmaṇa," in Atti del Sesto e del Settimo Convegno Nazionale di Studi Sanscriti, Venezia 23 novembre 1990-Palermo 20-21 maggio 1993, gen. ed. Oscar Botto, ed. Saverio Piano e Victor Agostini (Torino: CESMEO, 1998), 261-74; Maria Piera Candotti, and Tiziana Pontillo, "La realtà della lingua e le astrazioni dei grammatici: parole, frasi e segmenti nello sviluppo della riflessione linguistica indiana," in L'India e la parola. Volume monogr. di "Humanitas" 61 (3/2006), ed. Alberto Pelissero, 399-460, 414-17.

25 Eggeling's translation of paro'ksa is almost systematically "mystic." See ŚatapathaBrähmana According to the Text of the Mädhyandina School, transl. Julius Eggeling (Motilal Banarsidass, Delhi 1963-1978 [Oxford 1882-1900]).

26 Cf. ŚBM 14.6.11.2.

27 This passage is quoted from The Tändyamabäbrähmana Belonging to the Sämaveda with the Commentary of Sāyañācārya, ed. A. Cinnasvāmī Śāstrī, and Pațtābhīrāma Śāstrī (Benares: Krishnadas-Gupta, 1935-1936 [2 vols]).

28 It sometimes also deals with a motivated polysemy. E.g. in the example quoted above, the word-form rukman somehow denotes both a plate and the light of the Sun.

In Nir 10.8 this etymon occurs as one among 15 proposals.

30 This ritually planned replacement of words with synonyms and equivalent periphrases was already underlined by Louis Renou, "Art et religion dans la Poétique Sanskrite: le 'jeu des mots' et ses implications," Journal de Psychologie Normale et Pathologique 44, 1-2 (1951): 280-85: "La férie appelée Upahavya comporte des mots remplacées par des synonymes voilés, ainsi soma par indu. [...] le langage doit être 'courbé,' c'est à dire à double entendre ou brouillé par l'usage de synonymes” (ibid.: 285)

31 As far as this last terminological pair, see also Louis Renou, and Liliane Silburn, "Nirukta and Anirukta in Vedic," in Sarüpabbārati, Volume in Honour of Lakshman Sarup, Hoshiarpur, 1954, 68-79; Klaus Mylius, "Der Upahavya. Ein Vedischer Opferritus," Annals of the Bhandarkar Oriental Research Institute, 58/59, (1977-1978): 203-20, 208-10.

This passage is quoted from The Baudhāyana-Śrautasütra, ed. and trans. Chintaman G.

Kashikar (New Delhi: IGNCA and Motilal Banarsidass, 2003 [4 vols]).

33 This passage is quoted from Hari G. Ranade, Lätyāyana-Śrauta-Sütra (New Delhi: IGNCA, Motilal Banarsidass, 1998).

$34 \mathrm{JB}$ is quoted from Jaiminìya Brähmana of the Samaveda, ed. Raghu Vira, and Lokesh Chandra (Delhi: Motilal Banarsidass 1986 [Varanasi 1955]). Another piece of evidence is a commentary on Ásvalāyanaśrautasütra 9.7.28-quoted from The Śrauta Sütra of Ásvalāyana, with the Commentary of Gārgya Närāyaṇa, ed. Rāmanārayaṇa Vidyāratna (Calcutta: The Asiatic Society, 1864-1874), which connects the upabavya precisely with the Chāndogya tradition. The earliest occurrence of the term upabárya is AVŚ 11.7.15 but it merely denotes an "added oblation" according to Whitney's translation (Atharva-Veda Sambitā, transl. William D. Whitney (Delhi: Motilal Banarsidass 1962 [Cambridge, Mass., 1905]) and also to Mylius (1977-1978: 204). It is however noteworthy that in the AVŚ passage the upabavya is mentioned alongside "sacrifices arranged in secret" (yajñá gúbā hitáb̆).

35 We are hinting at the brabmodya context, see e. g. Louis Renou, and Liliane Silburn, "Sur la Notion du Brahman," Journal Asiatique 1949 [repr. in L'inde Fundamentale, ed. Charles Malamoud (Paris: Hermann 1978)]: 83-116, 87-9; Louis Renou, "L'enigme dans la Littérature ancienne de l'Inde," Diogène 29, (1960): 38-48; Jan C. Heesterman, The Ancient Indian Royal Consecration, The Rajjasūya Described According to the Yajus Texts and Annoted ('S Gravenhage: Mouton \& Co., 1957), 150-52; Paul Horsch, Die vedische Gäthā- und ŚlokaLiteratur (Bern: Francke Verlag, 1966), 405-10; Ludwik Sternbach, Indian Riddles. A Forgotten Chapter in the History of Sanskrit Literature (Hoshiarpur: Vishveshvaranand Vedic 
Research Institute, 1975), 16-8; George Thompson, "The Brahmodya and Vedic Discourse," Journal of the American Oriental Society 117, (1997): 13-37.

36 See e.g. Louis Renou, Les pouvoirs de la Parole dans le Rgveda (Paris: de Boccard, 1955), 18; Edwin Gerow, Indian Poetics (Wiesbaden: Harrassowitz, 1977), 220.

37 These examples are defined as samvijinätāni "well known" - "communément connus" according to Emilie Aussant, Le nom propre en Inde. Considérations sur le mécanisme référentiel (Lyon: ENS, 2009), 45. Cf. The Nighantu and the Nirukta. The Oldest Indian Treatise on Etymology, Philology and Semantics, crit. ed. and trans. Lakshman Sarup (Delhi: Motilal Banarsidass, 1920-1927), where samvijinätāni is translated as "conventional."

38 For an explanation of all these objections, although oriented to a different aim, see Pontillo (1998: 261-74), and for the discussion of some technicalities involved in the third objection, see Candotti, and Pontillo (2006: 399-460, 411-4).

39 Yāska preferably selects the words whose meaning cannot be explained merely with the help of grammar as the specific object of exegetic/paretymological science. On the complementarity between grammar and nirukta science, see Pontillo (1998, 272-73) and Candotti, and Pontillo (2006: 399-460: 402-04).

40 For the reconstruction of the usage of this term in Kātyāyana and Patañjali, see Maria Piera Candotti, and Tiziana Pontillo (2010: 41-61, 42); Tiziana Pontillo, "Where the sense is intended although the corresponding speech unit is not employed': the ekaśeșa case," in Proceedings of the 15th World Sanskrit Conference, Delhi 5-10 January 2012 (Vyäkarana Session), ed. George Cardona (New Delhi: D.K. Printworld, 2013), 97-132; Pontillo (2013, 109-22); Maria Piera Candotti, and Tiziana Pontillo, "Svabhāva in Grammar: Notes on the Early History of a Philosophical Term," in The Human Person and Nature in Classical and Modern India (Pisa, Rome: Fabrizio Serra Editore, 2015), 85-110 (Supplemento $\mathrm{n}^{\circ} 2$ alla Rivista degli Studi Orientali, N.S. 88).

41 For a complete survey of Pannini's rules devoted to the zero-replacements and the relevant earliest commentaries, see Tiziana Pontillo, "Allomorfi e morfema 'Zeromorfi' in Pāṇini: sostituzione di morfemi con zero fonico" "“Glottologia e Filologia" XII Ciclo 1996-1999), Italy: Faculty of Arts and Humanities of the University of Milan, 1999; for the relevant terminology, see Tiziana Pontillo, 'Il prototipo e le regole specifiche della letteratura rituale come modello della tecnica di sostituzione di Pāninini: il verbo lup- e il sostantivo lopa- nei Kalpa-Sūtra,' Annali della Facoltà di Lettere e Filosofia dell'Università degli Studi di Cagliari 21 (58), 2003 [2004], 5-42; for some specific cases, Tiziana Pontillo, "Derivazione denominale metonimica con zeromorfi di tipo LUP in Pāninini," Atti del Sodalizio Glottologico Milanese, 40 (2000) [2004], 105-49; Tiziana Pontillo, 'Once Again on Vyakti-Vacane in Astāadhyāȳ 1.2.51: Śravanah/Śravanāa' Rivista di Studi Sudasiatici 4 (2010): 97-126; for a speculative interpretation of Pānini's way/method of dealing with the zeroreplacements, see Candotti, and Pontillo (2013: 99-153, 129-30) for the connection between the zero-replacement device and the grammatical descriptive method of the rule-extensions, see Elisa Freschi, and Tiziana Pontillo, Rule-extension Strategies in Ancient India: Ritual, Exegetical and Linguistic Considerations on the Tantra- and Prasanga-Principles (Frankfurt: Peter Lang 2013), 117-8.

42 Even though these morphs can be regularly abstracted by means of the process of comparison between continuum and discontinum (anvaya and vyatireka).

43 M 1.241 ll. 5-6 (ad Vt 29 on A 1.2.64): yo hi gäm ásva iti brüyäd asvam vā gaur iti na jätucit sampratyayah syät, "If one calls a cow a horse or a horse a cow (as a mother which is called 'father' in the dual form pitarau) there would possibly be no comprehension (of the intended sense)."

44 Thus, the invention of the fundamental pattern of substitution may have been determined by the sacred belief in this permanent relation, along with the parallel technical need for the symmetry on which the scientific description of morphology could be arranged with little difficulty. This substitution pattern was then able to account for all 
the exceptions to the one-to-one principle of correspondence, such as the phenomena of synonymy and homonymy and the so-called denotation in absentia, by focusing on the whole (even inflected) word or its sub-units.

Kraus thinks that the archaic conception of the biunique word-object relation was exceeded in the fifth BCE. See Manfred Kraus, Name und Sache. Ein Problem im frühgriecbischen Denken (Amsterdam: B. R. Grüner, 1987).

Greek reflection on language begins in occasional forms in the archaic poems, which record the first and naive reflections about the lability of the relation between language and reality, or even between speeches and the speaker's actual intentions. Cf. Il. 20.24255, Od. 19.203, Hes. Op. 78, Th. 226-232. Paul Mazon, Homère. Iliade (Paris: Les Belles Lettres, 1957); Victor Bérard, L'Odyssée (Paris: Les Belles Lettres, 1967); Martin L. West, Hesiod. Theogony (Oxford: Oxford University Press, 1966); Martin L. West, Hesiod. Works and Days (Oxford: Oxford University Press, 1978).

Egbert J. Bakker, A Companion to the Ancient Greek Language (Malden MA-Oxford: Wiley Blackwell, 2010); Hermann Fränkel, Dichtung und Philosopbie des früben Griechentums. Eine Gescbicbte der griechischen Epik, Lyrik, und Prosa bis zur Mitte des fünften Jabrbunderts (Munich: Beck, 21962).

48 Werner Jaeger, La teologia dei primi pensatori greci (Firenze: La Nuova Italia Editrice, 1961), 111-12; Manfred Kraus, Name und Sache. Ein Problem im frübgriechischen Denken (Amsterdam: B. R. Grüner, 1987), 30-41.

Cf. Daniele Gambarara, Alle fonti della filosofia del linguaggio (Roma: Bulzoni Editore, 1984), $118-29$.

50 Cf. ŚBM 1.1.4.4. (seventh century BCE) in which the black antelope skin is called cárman by humans and sárman by gods.

51 Cf. Mäbäbhärata 1.69.33, in which the name Sarvadamana-, given by the ascetics to Sakuntalā's son, was changed into Bharata, which defines the son in relation to his father - The Mahäbhärata, crit. ed. Vishnu S. Sukthankar, Sripad K. Belvalkar, and Parashuram L. Vaidya (Poona: Bhandarkar Oriental Research Institute, 1933-1971; 19 vol.s.). See Tiziana Pontillo, "Il formulario delle paretimologie degli antroponimi nel Mahābhärata," in Atti dell'Ottavo Convegno Internazionale di Studi Sanscriti, Torino, 20-21 ottobre, 1995, ed. Irma Piovano, and Victor Agostini (Turin: Edizioni dell'Orso 2001), 97-117.

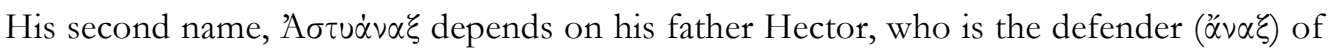

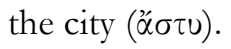

Cf. Hes. Th. 197, 272.

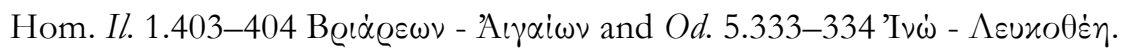

55 Kirk: "It is surprising to find this concept stated [...] of plural beings." See: Geoffrey S. Kirk, John E. Raven, Malcolm Schofield, The Presocratic Pbilosophers (Cambridge: Cambridge University Press, 1983), 56. The same principle is attested in the Orphic tradition, as Gambarara observes. Cfr. Gambarara (1984: 169-71).

56 Kirk (21983: 57, 71); Giorgio Colli, La sapienza greca. Epimenide, Ferecide, Talete, Anassimandro, Anassimene, Onomacrito, Vol. 2, 275, n. 9 A 1 (Milano: Adelphi, 1978); Rudolf Pfeiffer, History of Classical Scholarship from the Beginnings to the End of the Hellenistic Age (London: Oxford University Press, 1968), 12; Werner Jaeger, La teologia dei primi pensatori greci (Firenze: La Nuova Italia Editrice, 1961), 111. Ż่s, "who lives," and Xeóvos, "time," are both paretymological forms for the traditional Zeús and Keóvos.

57 Fr. 22 B 15 Diels - Kranz [DK]. See: Hermann Diels, and Walther Kranz, Die Fragmente der Vorsokratiker (Berlin: Weidmannsche Verlagsbuchhandlung, 1956); fr. 93 Fronterotta. Tr. Kahn.

59 Charles H. Kahn, The Art and thought of Heraclitus (Cambridge: Cambridge University Press, 1979), 263-66; Gambarara (1984: 246, n. 10). 
60 Cf. frr. 92, $93 \mathrm{Kahn}(=$ fr. $22 \mathrm{~B}$ 62, $88 \mathrm{DK})$.

61 Fr. 22 B 67 DK; fr. 28 Fronterotta.

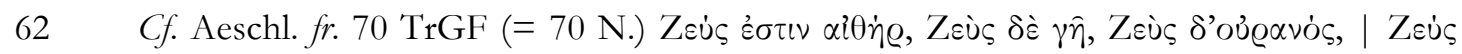

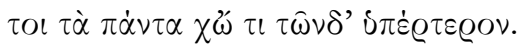

63 Cf. Francesco Fronterotta, Eraclito. Frammenti (Milano: BUR, 2013), 97-100; Marcel Conche, Héraclite. Fragments (Paris: Presses Universitaires de France, ${ }^{31991), ~ 379-83 ; ~ J e a n ~}$ Bollack, and Heinz Wismann, Héraclite ou la séparation (Paris: Éditions de Minuits, 1972); Kahn (1979 : 84-5, 276-81).

64 If we accept the integration of $\pi \hat{v} \varrho$, the similarity of this Heraclitaean fragment with

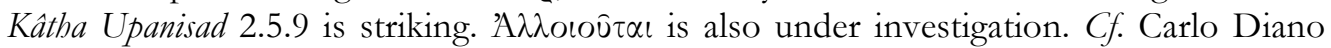
and Giuseppe Serra, Eraclito. I frammenti e le testimonianze (Milano: Arnoldo Mondadori Editore, 1980), 142-43.

65 Diano, and Serra (1980: 141).

66 Miroslav Marcovich, Rodolfo Mondolfo, and Leonardo Tarán, Eraclito. Testimonianそe, Imitazioni e Frammenti, trans. Piero Innocenti (Milano: Bompiani, 2007), 668.

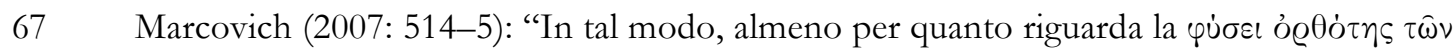

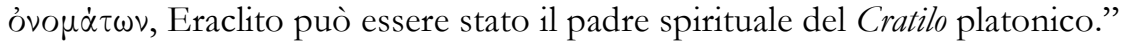

68 Fr. 79 Kahn; fr. 66 Fronterotta; fr. 39 Marcovich. Etym. Magn., s. v. ßioc. The text of the Etym. Magn. is $\tau \hat{\omega} \tau \dot{\omega} \xi \omega$, with an ỡv that should preferably not be expunged, as Gambarara (1984: 246, n. 2) observes.

69 Conche (31991: 421).

70 Thomas M. Robinson, Heraclitus. Fragments (Toronto - Buffalo - London: University of Toronto Press, 1987), 111, fr. 48. See also Fronterotta (2013: 264-5, n. 2): "Questo punto di vista [...] colloca certamente Eraclito tra le fonti della sezione etimologica del Cratilo platonico [...] collocandosi evidentemente, in tale ottica, nella prospettiva 'essenzialista' della naturale corrispondenza fra nome e cosa."

71 Lorenzo Miletti, Linguaggio e metalinguaggio in Erodoto, in Annali dell'Istituto Universitario Orientale di Napoli (Pisa - Roma: F. Serra, 2008), 26.

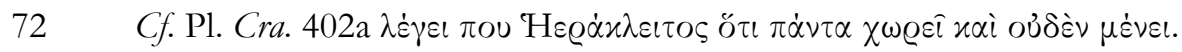

73 Mil is quoted from Milindapañha, ed. Vilehelm Trenckner (London: Luzac, 1962 [1880]).

$74 \quad$ M $1.1361 .8 \mathrm{Vt} 10$ ad A 1.1.56: ekadeśavikertam ananyavat, which corresponds to Paribhäsāa 37. See The Paribhäsenduśekhara of Nāgojībhatta, ed. and explained by Franz Kielhorn, Part I, Critically edited with the Commentary Tattvādarśa of M.M. Vasudev Sh. Abhyankar (Poona: Bhandarkar Oriental Research Institute 2001 [1962]); Part II Translation and Notes by Kashinath V. Abhyankar (Poona: Bhandarkar Oriental Research Institute, 2001 [1960]).

75 M 1.23 11. 24-27 ad Śivasūtras 3-4 Vt 5; M 1.136 11. 21-22 ad A 1.1.56 Vt 11; M 3.2 ll. 1316 ad A 6.1.1 Vt 13: $c f$. Maria Piera Candotti, and T. Pontillo, "The (In)separable Parts of a Plant in the Mahābhașya Imagery i.e. How Nature May Inspire a Grammarian," in Pandanus '07, ed. Jaroslav Vacek (Prague: Signeta, 2007), 43-63.

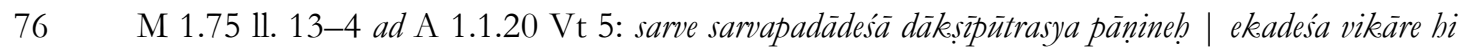
nityatvam nopapadyate.

77 MN is quoted from: The Majjhima-Nikāya, Vol. 1, ed. Vilhelm Trenckner (London: Luzac, 1964 [1888]).

78 This passage is emphasized in Kulatissa N. Jayatilleke, Early Buddhist Theory of Knowledge (New York: Routledge, 2008 [1963]), 314-5.

79 It is nevertheless noteworthy that, whereas the Brāhmanas sometimes resorted to bizarre etymologies in order to illustrate some ritual explanation, in the Pāli sources we often find some wrong definitions of specific terms, i.e. some historically incorrect explanations, targeted on the intentional introduction of a new use of these terms. See 
Jayatilleke 2008: 297. An example (rüpa) is analysed in Tiziana Pontillo, "A Dense Definition of Rūpaka. What does rüpyate mean in Bhāmaha's Kāvyālaṃkāra 2.21," in Sanskrit Studies 4, (2015), ed. Upendra Rao (Delhi: D. K. Printworld, 2015), 145-68, 14851.

80 See The Digha Nikaya, ed. Thomas W. R. Davids, and Joseph E. Carpenter (London: Oxford University Press/London: Luzac, 1947-1960 [1890; 1903; 1911]).

81 These dharmas are "classified abstractly by distinctive intrinsic nature" (svabbäva): cf. C. Cox, "From Category to Ontology: the changing Role of Dharma in Sarvāstivāda Abhidharma," Journal of Indian Philosophy 32, (2004): 543-97, here p. 553.

82 As pointed out and reconstructed by Bronkhorst (1987), they could match with the two expressions padasamghäta and varnasamghäta, which are merely employed as examples in $\mathrm{M}$ 2.104 11. 2-3 ad A 3.2.49 Vt 3, but likely derived by means of the agent affix aN (A 3.4.67) in the sense of "what collects sound/-s" and "what collects word/-s" respectively i.e. as "individual word" and "individual sound," both to be considered as indivisible and independent entities in the real language. They should not thus be derived by means of GHaÑ (A 3.3.18) in the sense of a "collection of sounds" and "collection of words" respectively.

83 ChUp is quoted from Eighteen Principal Upanisad, ed. Vishnu P. Limaye, and Ranganath D. Vadekar, vol. 1 (Poona: Vaidika Saṃșodhana Maṇḍala, 1958).

84 àdeśa "rule of substitution." See trans. Patrick Olivelle, The Early Upanisads. Annotated Text and Translation (Oxford: Oxford University Press, 1998), 247.

85 vācārambha 'verbal handle' (ibid.).

86 This is a controversial passage, especially as regards the segmentation of väcarambhanam as a compound. See Johannes A. B. Van Buitenen, "Vācārambhaṇam," Indian Linguistics 16, (1955): 157-62; or as an external sandhi (with scriptio continua) for vācā àrambhanam Franciscus B. J. Kuiper, "Vācārambhaṇam," Indo-Iranian Journal 1, 2, (1957): 155-59; as far as the syntactic role of the three nominative cases väcärambhanam vikäro nämadheyam and of agner are concerned, see Johannes A. B. Van Buitenen, "Vācārambhaṇam reconsidered," Indo-Iranian Journal 2, (1958): 295-305; Franciscus B. J. Kuiper, "Vācārambhaṇam II," Indo-Iranian Journal 2, (1958): 306-10; Johannes A. B. Van Buitenen, 'Correction,' Indo-Iranian Journal 4, (1960): 67. However, the speculative point had already been clearly highlighted by Louis Renou, Les pouvoirs de la Parole dans le Rgveda (Paris: de Boccard, 1955), 18, 23. The ontological individual entity of agni is denied because the individuality of agni has language as sole point of support. As Van Buitenen concludes: "everything is reducible to the three ruppas and can thus be known and recognized through them, in the same way as clay pots can be recognized through clay." See Van Buitenen (1960: 67). Patañjali’s aforementioned conclusion on the wholepart relationship seems to be tuned to this teaching by Uddālaka interpreted as "a powerful tool for providing an integrative comprehension of the seemingly fragmented reality," as it is explained by Paolo Visigalli, "Continuity and Change in Chāndogya Upanișad 6.14," in Puspika: Tracing Ancient India Through Texts and Traditions, ed. Giovanni Ciotti, Alastair Gornall, and Paolo Visigalli, $\$ 9$ (Oxford: Oxbow Books: 2014).

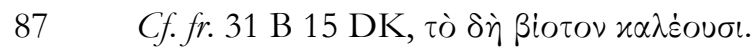

88 The manuscripts have a lacuna here.

89 Diels accepts Bachet de Meziriac's conjectural reading of a negative conjunction before

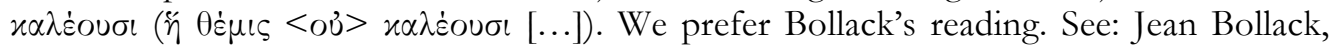
Empédocle, 2. Les origines: édition et traduction des fragments et des témoignages; 3. Les origines: commentaires 1 et 2, vol. 3, 94-95 (Paris: Gallimard, 1969), Cf. Carlo Gallavotti, Empedocle. Poema fisico e lustrale (Milano: A. Mondadori, 1975), 180-181, nn. 9, 10; Gambarara (1984, 237). 
90 Here and in the subsequent passages where Graham translates "names exist/do not exist by nature," we mean "the relation between the names and the objects they denote is/is not by nature."

91 Daniel W. Graham, The Texts of Early Greek Pbilosophy. The Complete Fragments and Selected Testimonies of the Major Presocratics, vol. 2, 606 fr. 167 [F48] (Cambridge: Cambridge University Press, 2010): '̇ं $\pi^{\prime} \alpha \lambda \lambda \eta \lambda \alpha$ codd. '̇ $\pi \dot{\alpha} \lambda \lambda \eta \lambda \lambda \alpha$.

92 Tr. Graham.

93 Donatella Di Cesare, La semantica nella filosofia greca (Roma: Bulzoni, 1980), 51-88.

94 Frr. 80 A 1 DK (50), 80 A 14 DK (217), 80 B 4 DK. See: Michele Corradi, Protagora tra filologia e filosofia. Le testimonianze di Aristotele (Pisa, Rome: Fabrizio Serra Editore, 2012), $62,73,80-9$.

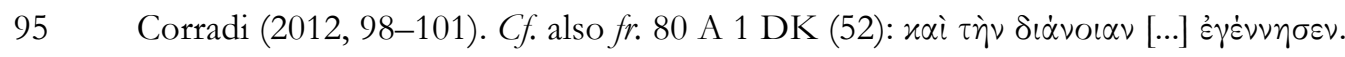

96 Fr. 80 A 28 DK. The scholars are divided into those who think that Protagoras considers that $\mu \hat{\eta} v i s$ and $\pi \dot{\eta} \lambda \eta \xi \xi$ are masculine due to the reference to a manly field, and those who are convinced that this is for morphological reasons: in fact, for the sofist, $-\varsigma$ and $-\xi$ are more suitably masculine desinences. See Corradi (2012: 152-3, 163-4). For Corradi (ibid:174), Protagoras follows the traditional method which measures the correctness of the names from their adherence to reality, provided that, for the sophist, reality and human opinion $(\delta \dot{\delta} \xi \alpha)$ coincide.

97 For more details $c f$. Charles Segal, "Protagoras' Orthoepeia in Aristophanes 'Battle of the Prologues”" (Frogs, 1119-97), Rheinishes Museums für Philologie 113, (1970): 158-62; Gian Franco Nieddu in Patrizia Mureddu, and Gian Franco Nieddu, "Furfanterie Sofistiche: omonimia e falsi ragionamenti tra Aristofane e Platone," Eikasmos. Quaderni Bolognesi di Filologia Classica Studi 2 (Bologna: Patron, 2000), 35-9; Corradi (2012: 127, 161).

98 Pfeiffer (1968: 39-40).

99 Fr. 84 A 1 DK.

100 Fr. 84 A 11, 16 DK.

101 Frr. 58, 59, 63-65 Mayhew, 84 B 4 DK.

102 Fr. 50 Mayhew (on the term $\delta \varepsilon \iota v o ́ \varsigma$ 'terrible,' but also 'terrific').

103 Robert Mayhew, Prodicus the Sophist. Text, Translations, and Commentary, xvi (Oxford: Oxford University Press, 2011).

104 Tr. Graham.

105 The theoretical debate about the problem of asymmetry also appears in scenes from the classical theatre. Cf. Eur. Hipp. 383-387 about $\alpha i \delta \omega$ 's, which can mean 'modesty' or 'shame,' and Ar. Nu. 636-42 about $\mu \varepsilon \dot{\varepsilon} \varrho \alpha$ 'the number of rhythms that a line can contain' or 'measures of capacity.' Cf. William S. Barrett, Euripides. Hippolytus (Oxford: Oxford University Press, 1964), 230-31; Laura McClure, Spoken like a Woman. Speech and Gender in Athenian Drama (Princeton: Princeton University Press, 1999), 131; Alan H. Sommerstein, The Comedies of Aristophanes. Clouds, Vol. 3 (Chicago - Warminster: Bolchazy Carducci Publishers/Aris \& Phillis Publishers, ${ }^{2}$ 1984).

106 Nonetheless we cannot exclude that in ancient Greece some connections also exist between the sacrificial lexicon and metrical terminology, as shown by Jesper Svembro, "Il taglio della poesia. Note sulle origini sacrificali della poetica greca," Studi Storici 25, 4, (1984): 925-44; cf. Walter Belardi, Filosofia, grammatica e retorica nel pensiero antico, 19 (Rome: Ateneo, 1985).

107 We hint at Kahrs (1984, 152 ff.; 1998, 159 ff.), who recognizes it as a basic mechanism in the whole exegetic-semantic tradition and particularly in the Nirukta genitive formulas (X replaces Y). 
108 Cf. Bice Mortara Garavelli, Manuale di retorica (Milan: Tascabili Bompiani, 52000), 19: "La nascita della retorica si connette pure alla scoperta e al riconoscimento del valore conoscitivo ed educativo che ha la riflessione sulla lingua"; Vickers (1994 [1988]: 40). See Brian Vickers, Storia della retorica (Bologna: Il Mulino 1994 [1988]), 40. 